IZA DP No. 10389

The 'Informality Gap': Can Education Help Minorities Escape Informal Employment? Evidence from Peru

Juan Gabriel Delgado Montes Javier Corrales Prakarsh Singh

November 2016 


\title{
The 'Informality Gap': \\ Can Education Help Minorities Escape Informal Employment? Evidence from Peru
}

\author{
Juan Gabriel Delgado Montes \\ Amherst College \\ Javier Corrales \\ Amherst College \\ Prakarsh Singh \\ Amherst College, University of Pennsylvania \\ and IZA
}
Discussion Paper No. 10389
November 2016

\author{
IZA \\ P.O. Box 7240 \\ 53072 Bonn \\ Germany \\ Phone: +49-228-3894-0 \\ Fax: +49-228-3894-180 \\ E-mail: iza@iza.org
}

\begin{abstract}
Any opinions expressed here are those of the author(s) and not those of IZA. Research published in this series may include views on policy, but the institute itself takes no institutional policy positions. The IZA research network is committed to the IZA Guiding Principles of Research Integrity.

The Institute for the Study of Labor (IZA) in Bonn is a local and virtual international research center and a place of communication between science, politics and business. IZA is an independent nonprofit organization supported by Deutsche Post Foundation. The center is associated with the University of Bonn and offers a stimulating research environment through its international network, workshops and conferences, data service, project support, research visits and doctoral program. IZA engages in (i) original and internationally competitive research in all fields of labor economics, (ii) development of policy concepts, and (iii) dissemination of research results and concepts to the interested public.
\end{abstract}

IZA Discussion Papers often represent preliminary work and are circulated to encourage discussion. Citation of such a paper should account for its provisional character. A revised version may be available directly from the author. 
IZA Discussion Paper No. 10389

November 2016

\section{ABSTRACT}

\section{The 'Informality Gap': Can Education Help Minorities Escape Informal Employment? Evidence from Peru}

Discrimination in formal labor markets can push discriminated groups into labor informality, where wages are lower and pensions scarce. In this paper, we explore whether education offsets discrimination by empowering discriminated groups to successfully compete for formal jobs. Specifically, we calculate the returns to education on formal employment for a discriminated group (indigenous Peruvians). We find that certain education levels -primary and tertiary-allow indigenous workers equal access to formal jobs. But, for indigenous workers with only secondary education, we find an "informality trap" where returns to secondary education are 6.7 percentage points lower, a difference larger than the net returns of primary education. We find that differences in education quality across districts, more than migration and industry-specific patterns, are the main drivers of this effect. These findings have policy implications suggesting improvements to quality are essential for secondary education to empower discriminated groups to successfully compete in labor markets.

JEL Classification: E26, J46, I26, H55, J71

Keywords: education, informal labor markets, social security, exclusion, Latin America

Corresponding author:

Prakarsh Singh

Department of Economics

Amherst College

P.O. Box 2201

Amherst, MA 01002-5000

USA

E-mail: psingh@amherst.edu 


\section{Introduction}

Education can help individuals develop employable skills and get access to new labor markets. However, societal or labor force discrimination could undo the returns to education for certain social groups by forcing members of non-dominant groups into informal labor markets (UNDP 2013). Lack of access to formal markets usually precludes social security benefits and pensions. Without social security and pensions, individuals are more at risk of poverty (Barrientos 2005, 2011; van der Klaauw and Wolpin 2005; Bernheim et al. 2015). Informal workers are considerably more 'vulnerable' - likely to be in poverty in the future — and lack numerous socially sanctioned protections as compared to formal workers (Barrientos 2011; ILO 2002).

To what extent can education counteract discrimination, and thus allow members of discriminated groups to gain access to formal jobs? In developing countries where labor informality is commonplace, education may prove to be a useful tool to align educated workers with the highly productive formal sector. Latin America has a significant informal sector, estimated at around 40 percent of GDP (Schneider 2015) and comprising over 50 percent of the region's workers (Vanek et al. 2014). In comparison, in the Middle East and North Africa the informal sector amounts to approximately 30 percent of GDP and 45 percent of workers. Despite having higher per capita income and higher educational enrollment rates, Latin America has far more informality than the Middle East and North Africa (World Bank 2016).

Although numerous studies estimate the wage returns to education, few have focused on the returns to education as they pertain to formal employment, and to our knowledge, none in the 
context of labor discrimination. ${ }^{1}$ Studying the relationship between formal education and wages is a well-established field, rooted in human capital theory (Schulz 1961; Becker 1964; Mincer 1974). In general, the returns to schooling are higher for primary education, but still large for secondary and tertiary levels. These findings have led others to explore the role of education on other social outcomes, such as employment (Bloch and Smith 1977; Mincer 1989), the demand for schooling (Jensen 2010).

However, few studies have explored the returns to education on finding formal employment. Some studies have looked at the returns to discriminated groups, such as women or non-dominant ethnic groups (Fryer et al. 2013, Ñopo 2012; Cunningham and Jacobsen 2008; Neal and Johnson 2006). These empirical studies evoke unexplained variation in wages after incorporating numerous individual and socio-economic controls. They find significant earning gaps between discriminated and non-discriminated groups. ${ }^{2}$

However, as much as these studies reflect social realities, given that discrimination is not directly observed, certain authors argue that these approaches do not accurately illustrate its effects (Charles and Guryan 2011; Fryer 2010). Overcoming these limitations is notoriously difficult with

\footnotetext{
${ }^{1}$ Some notable exceptions are Dabos and Psachoropolous (1991), looking at the returns to education on wages for self-employed workers, and Canavire-Bacarreza (2008) with a preliminary exploration of ethnic wage gaps across the formal and informal sectors.

${ }^{2}$ For example, Nopo (2012) finds that the earnings gap in Latin America between ethnic minorities (jointly indigenous and Africans) relative to non-minorities ranges from 27 percent to 57 percent of a minority worker's wage. The lower bound of this range is still larger than the 16 percent gender earnings gap estimated for the same region.
} 
current data and research methods. Consequently, some researchers deploy experimental and quasi-experimental methods to try to observe discrimination based on skin color, caste, religion, and physical appearance directly and through specific channels (Datta and Pathania 2015; Deshpande and Sharma 2015; Bertrand and Mullainathan 2004; Pager 2007; Pager et al. 2009; Hamermesh and Biddle 1994).

Still, the effect of education on labor informality has yet to be thoughtfully studied. If societal discrimination is dominant, we expect to observe that education has a much smaller effect on labor informality for discriminated groups. However, if education is a useful tool for empowerment, we expect to observe similar returns to education for discriminated and nondiscriminated groups.

Peru is a compelling case to study the impact of education on informality across discriminated groups for three reasons. First, Peru's informal sector is well understood (de Soto 1989; Saavedra and Chong 1999). In addition, Peru has a sizeable indigenous population that has historically been marginalized from economic and educational opportunities. Estimates based on self-identification place the figure at around 40 percent of the population (Sulmont 2011). ${ }^{3}$ Finally, the country has undergone rapid economic growth, stable democracy and a significant reduction of income inequality since the $1990 \mathrm{~s},{ }^{4}$ so one cannot easily argue that Peruvians have been devoid of opportunities for social mobilization.

\footnotetext{
${ }^{3}$ Estimates vary widely depending on metric used: from 19.2 percent based on native language to almost 75 percent based on parental birthplace (Sulmont 2011).

${ }^{4}$ Between 1997 and 2006, the Gini coefficient for household income declined from 0.54 to 0.49 (López-Calva and Lustig 2010).
} 
To assess the impact of education on the likelihood of finding formal employment and explore whether these effects are significantly smaller for discriminated minorities (indigenous Peruvians), we implement a differences-in-differences fixed effects specification. Our findings are two-fold. First, education does help discriminated groups find formal employment at primary and tertiary levels. This is an important finding because it reveals that education is not a wasteful investment - it can offset discrimination. Second, there is an exception: the returns to education for indigenous individuals are considerably lower at the secondary level. This is important because it indicates an 'informality gap' between indigenous and non-indigenous individuals present only at intermediate levels of education. We conclude by ruling out possible channels and testing for the main mechanism that could be driving this disparity.

\section{Conceptual Framework}

Borrowing from Bloch and Smith $(1977,551)$ we posit that the relationship between education and formal employment is shaped by both supply and demand forces. On the supply side, more educated individuals will have more sophisticated and scarce skills. They may also be embedded in personal networks with greater exposure to formal employment, facilitating the finding of formal jobs (Munshi 2003; Montgomery 1991). On the demand side, formal firms will want to hire more educated workers where education, either by signaling or actual skills, indicates higher productivity (Corrales 2005; Spence 1977).

Note that there may be omitted variables that could be driving employment outcomes (see Figure 1). These may include an individual's demographic characteristics such as age, gender, residence, and marriage status. For example, younger workers often view informal employment as an entry point in the labor market before transitioning to formal work (Perry et al. 2007; Evans 
and Leighton 1990). Women are also more likely to be informal while balancing child rearing or facing exclusion from certain occupations (see Chen et al. 2006). Similarly, institutional arrangements governing labor markets, or differences in the state's enforcement capacity may influence the costs and benefits of informal employment. For example, decreases in labor benefits or increases in barriers to registration can encourage informal employment (Galiani and Weinschelbaum 2012; Saavedra and Chong 1999). Additionally, socio-economic factors including language (Chiswick et al. 2013), migration (Piracha et al. 2013; Calvó-Armengol and Jackson 2004), health and cultural preferences (Adams and Valdivia 1994) may also influence employment outcomes.

Figure 1 Conceptual framework: Factors shaping Access to Formal Markets

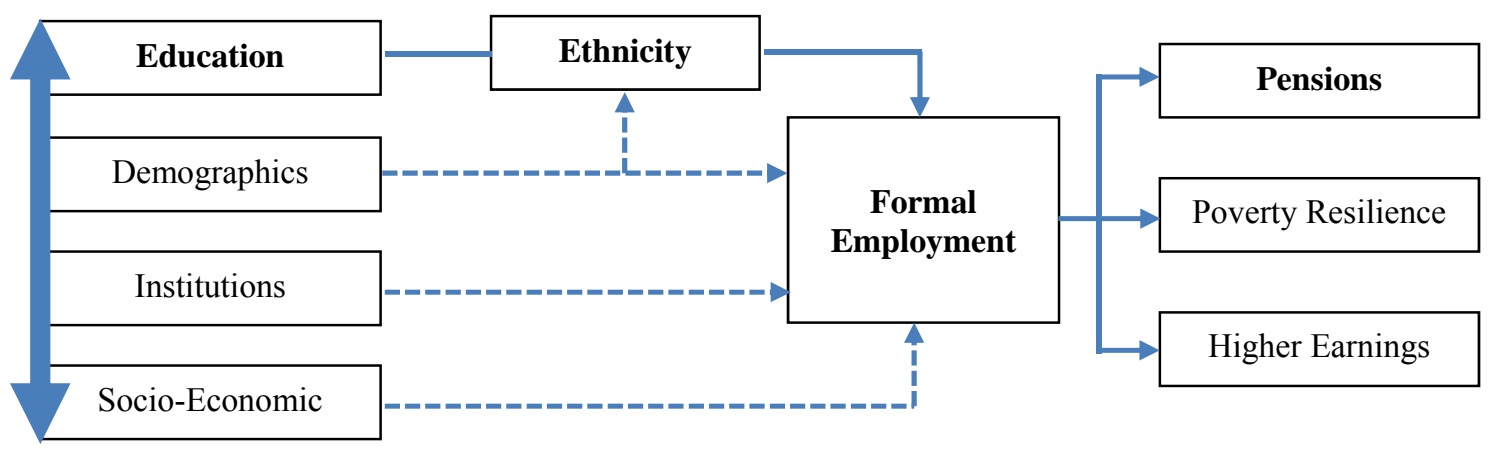

We control for several variables proxying for each channel and implement age and district fixed effects to control for time-specific and space-specific variations. Still, unobservable characteristics and measurement errors are more difficult to address with available data. To address 
these, we conduct a series of robustness checks, including a two-step Heckman selection model (see Section 6).

\subsection{Hypotheses}

There are 3 possible outcomes that can be posited as hypotheses on the relationship between education and societal discrimination (see Figure 2). ${ }^{5}$

H1: Returns to education are larger for the non-discriminated group than for the discriminated group

$\mathrm{H} 2$ : Returns to education are larger for the discriminated group than for the nondiscriminated group

H3: The returns to education are equal for discriminated and non-discriminated groups.

H1 implies that societal discrimination dominates the benefits of education to finding formal employment. In contrast, $\mathrm{H} 2$ implies that the benefits of education to finding formal employment are stronger for minorities, overcompensating for societal discrimination. If this hypothesis is correct we would expect to observe that for each additional level of education, the change in the

\footnotetext{
${ }^{5}$ This hypothesis assumes similar quality of education for the dominant and discriminated groups, an issue we address in the paper.
} 
probability of being formally employed is larger for the discriminated minority. $\mathrm{H} 3$ implies that the benefits of education to finding formal employment overcome societal discrimination, placing discriminated minorities and dominant majorities on an equal footing.

Figure 2: Hypotheses on returns to
$\Xi$ Dominant group
回 Discriminated group
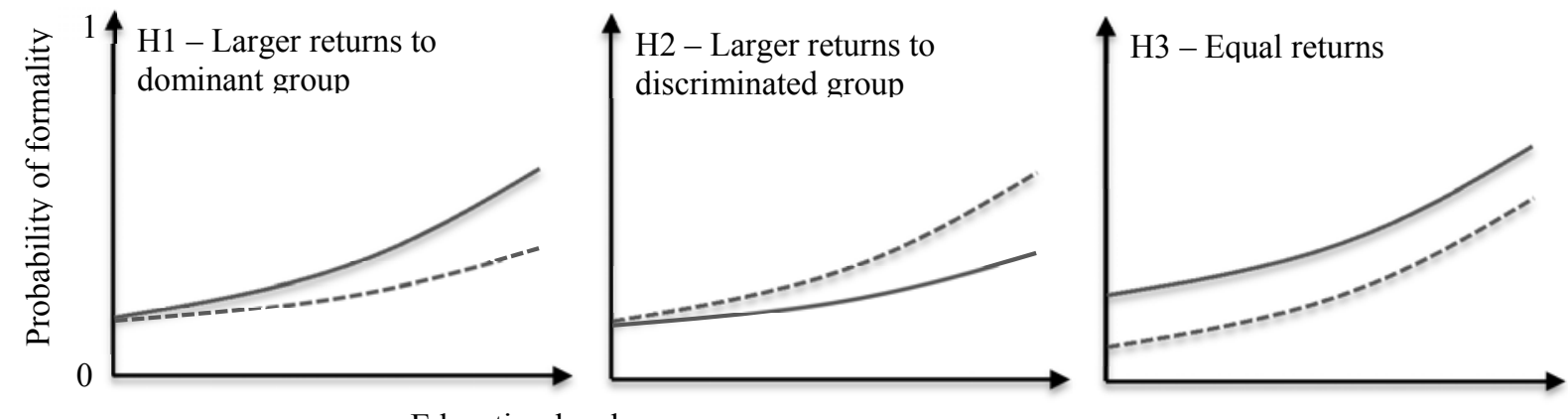

Education level 


\section{Measurement and Data}

Our main dependent variable is formality. ${ }^{6}$ To measure formality, direct methods are best suited given available data. ${ }^{7}$ These methods can be categorized as legalistic and productive (Perry et al. 2007).

\subsection{Legalistic Informality}

The legalistic approach to informality, popularized by Saavedra and Chong $(1999,99)$, focuses on the coverage and availability of social protections for workers. It illustrates the relationship between individual actors and the state, in particular the rule of law, because it is based on compliance with the established judicial, regulatory and institutional framework. Given that labor laws and regulations outline entitlements, benefits and rights, legalistic informality primarily measures the social benefits workers enjoy, rather than the nature of their employment. ${ }^{8}$

\footnotetext{
${ }^{6}$ Since Keith Hart (1973) coined the term 'informality' to describe the activities of Ghanaian unskilled workers, it has evolved into an umbrella term that reflects the heterogeneity of informality. Past decades have seen considerable research to measure and understand the informal sector. However, it is only recently that this literature has been compiled into extensive studies of the sector as in the ILO's (2013) manual.

${ }^{7}$ There are three main forms of measuring informality: (1) direct methods (2) indirect methods and (3) model methods.

${ }^{8}$ Studies have used indicators such as union membership, access to pensions, health insurance or registration with the national tax authority to identify legalistic informality. The benefits of this measure are threefold: first, these dimensions are easily captured by national household surveys;
} 
We use Gasparini and Tornarolli's (2009) adaptation of legalistic informality, which is based on access to pensions. Informality is thus defined as a dichotomous variable which takes the value 1 if the individual does not have the right to any form of pensions, and 0 otherwise. ${ }^{9}$ Although social security entails numerous other benefits such as unemployment insurance or health insurance, pensions are the broadest and most accessible category of social insurance found in national household surveys. Therefore, this measure is the most reliable indicator of informality.

\subsection{Productive Informality}

In contrast, the productive definition of informality focuses on the nature and status of the firm that employs a worker. The ILO (1991) refers to informal firms as those "with scarce or even no capital, using primitive technology and unskilled labor." This measure takes the premise that

second, employment entitlements and regulations do not change frequently; and third, it captures evasion by specific individuals, allowing a study of informality within large firms where formal standards may not apply to all employees (Perry et al. 2007). The main limitations are that these benefits and entitlements vary across countries, making cross-sectional comparisons difficult, and that not all countries include comparable questions in their surveys.

${ }^{9}$ Workers in Peru have access to two different forms of pensions: private pension plans known as SPP (Sistema Privado de Pensiones) and the public pension system known as SNP (Sistema Nacional de Pensiones). For example, individuals in the SNP must contribute for 20 years in order to be eligible for a pension whilst individuals in the SPP have no timed contribution requirement, but must contribute 13\% of gross income (Oficina de Normalización Previsional 2016). 
informal firms cannot access external financing, advertise, nor expand to an economically efficient scale.

To verify the robustness of our findings, we also implement Gasparini and Tornarolli's (2009, 18-19) definition of productive informality. Under this definition workers are separated into seven categories indicative of productive circumstances: (1) entrepreneurs, (2) salaried workers in large private firms, (3) salaried workers in the public sector, (4) salaried workers in small private firms, (5) skilled self-employed, (6) unskilled self-employed and (7) zero-income workers. Entrepreneurs are classified as individuals who directly employ others and small private firms are defined as having five or fewer workers. This measure is also a dichotomous variable equal to 1 if a worker belongs to categories (4), (6) and (7) and 0 if otherwise. ${ }^{10}$

Given that the legalistic definition is concerned with the wellbeing of workers, and that some of the categories used in the productive definition can be used to understand heterogeneous effects, we rely primarily on the legalistic definition.

\subsection{Informality in Peru}

Indigenous Peruvians face fewer opportunities for education, income and health (Ñopo 2012; Hall and Patriños 2006). Some of these disadvantages are viewed as part of the region's larger legacy of colonialism and exclusionary institutions (Engerman and Sokoloff 2001). Recent empirical literature has made some progress in quantifying the role of discrimination and

\footnotetext{
${ }^{10}$ The traditional definition also has its limitations, in particular the classification of entrepreneurs as formal given that they could be self-employed or operate in conditions of limited productivity, but hiring some number of workers.
} 
exclusion, where indigenous groups have been shown to have much reduced access to opportunities relative to mestizo (mixed) and white populations (Thorp and Paredes 2012; Trivelli 2005; De la Cadena 2000; Méndez 1996). For example, using experimental data Galarza et al. (2012) demonstrate that indigenous-sounding names in the capital city are far less likely to receive callbacks for jobs than equally qualified white-sounding names. ${ }^{11}$

Hernando de Soto's (1989) seminal study The Other Path, situated Peru as a rich ground for studying the causes and consequence of informality. Most remarkably, de Soto's focus on informal entrepreneurs in Lima allowed for the study of the causes (such as high barriers to entry) rather than the consequences of informality (such as the lack of property rights). Shortly afterwards, the 1993 Peruvian constitution and new legislation introduced significant changes to reduce labor market rigidities. In particular, this included new types of flexible contracts and the creation of a 'Unified Tax Payer Registry' (Registro Unico de Contribuyentes), which simplified and reduced the costs for self-employed workers and small businesses to register with the tax authority. ${ }^{12}$ Despite slight decreases since 2002, labor informality remains an enduring characteristic of Peru's economy, where in 2011 approximately 70 percent of workers were not

${ }^{11}$ This paper applies Bertrand and Mullainathan's (2004) experimental methodology to the Peruvian labor market.

${ }^{12}$ For a more detailed outline of changes in Peru's labor market see Saavedra and Chong (1999, 97-99). 
covered by social security compared to 50 percent for the region as a whole (ILO 2014; Vanek et al. 2014). ${ }^{13}$

\subsection{Ethnicity in Peru}

Another salient feature of the Peruvian economy is the marginalization of its large indigenous population. ${ }^{14}$ In this paper, we use self-identification, rather than language-based measures, to construct a binary variable equal to 1 if the individuals self-identify as Quechua, Aymara or Amazonian and 0 if otherwise. Self-identification is the preferred measure because it reduces the under-estimation of indigenous populations, and does not conflate the mechanism of language proficiency and general education, both of which may determine employment outcomes. ${ }^{15}$ However, in Section 7 we use native language as a robustness check our findings. We use two sources of data for ethnicity in Peru. First, individual-level data is from Peru's National Institute of Statistics and Information, drawing on the 2010 National Household Survey (ENAHO). EHAHO is a nationally representative survey carried out on a yearly basis with technical assistance from the United Nations Commission for Latin America and the Caribbean (ECLAC in Spanish). We draw on five survey modules: Individual and Household Characteristics, Education,

\footnotetext{
${ }^{13}$ India and Mali display the highest informality rates, above 80 percent of non-agricultural workers in the most recent studies

${ }^{14}$ Peru's Afro-descendant population is also subject to discrimination, see Galarza et al. (2015) and Miranda et al. (2013).

${ }^{15}$ For a comprehensive comparison of different approaches to measure ethnicity in Latin America see Gonzales (1994, p. 23-27).
} 
Employment, Democracy and Transparency, and Health. The sample size encompasses more than 20,000 households and 80,000 individuals randomly sampled at the departmental and national level.

The other source is district-level data from Peru's Ministry of Development and Social Inclusion, using figures from the Development Cooperation Fund (FONCODES). This data is available for 1999 and 2001. It includes social and demographic indicators, and expenditure figures for Peru's 1,817 administrative districts. The quantitative analysis in this paper focuses exclusively on the heads of households and their spouses for whom self-identification of ethnicity is available. ${ }^{16}$

Table I provides summary statistics. Unsurprisingly, indigenous workers are on average more likely to be informal by a large margin regardless of the measure of informality employed. In addition, indigenous individuals are far less likely to have completed either secondary or tertiary education, and are more likely to have incomplete primary education. Indigenous Peruvians are also more likely to live in rural areas and to have migrated to other parts of the country. Indigenous Peruvians are on average more likely to be self-employed and to work at microenterprises (firms with 5 or fewer workers). Overall, the identification of indigenous and non-indigenous groups clearly creates two characteristically different groups, where indigenous workers are poorer and less educated (Hall and Patrinos 2006; Ñopo 2012).

[Table 1 Goes Here]

\footnotetext{
${ }^{16}$ We opted for Peru's national survey, in place of employment-specific surveys because employment surveys do not include ethnicity identifiers. Peru conducts an employment-specific survey: Encuesta Permanente de Empleos (EPE).
} 


\section{Empirical Specification}

Our empirical analysis seeks to measure the differences in returns to education for indigenous and non-indigenous workers by means of a difference-in-differences fixed effects specification. Since employable skills are often measured in terms of completed levels of schooling, rather than a continuum of years, we interact each level of education with indigenous ethnicity. ${ }^{17}$ The above identification strategy can be expressed by the following regression framework:

(1) $Y_{i j t}=c+\tau_{j}+\varphi_{i t}+\alpha I_{i j t}+\beta P_{i j t}+\gamma S_{i j t}+\delta T_{i j t}+\theta\left(I_{i j t} * P_{i j t}\right)+\mu\left(I_{i j t} * S_{i j t}\right)+\rho\left(I_{i j t} *\right.$ $\left.T_{i j t}\right)+\sigma X_{i j t}+\varepsilon_{i j t}$

$Y_{i j t}$ refers to the dummy outcome variable for informality - either access to a pensionable job or 'productive' informality for individual $i$ born in period $t$, currently living district $j . I_{i j t}$ is a dummy indicating whether the individual self-identifies as indigenous. $P_{i j t}, S_{i j t}$ and $T_{i j t}$ are dummy variables indicating the individual's highest level of completed education, primary, secondary and tertiary levels, respectively. The coefficients for $P_{i j t}, S_{i j t}$ and $T_{i j t}$ give us that education level's estimated returns on informality relative to incomplete primary education, for non-indigenous workers. Consequently, the standalone $I_{i j t}$ dummy shows the difference in the likelihood of informality for indigenous workers relative to non-indigenous workers across all

\footnotetext{
${ }^{17}$ Some authors argue that education levels matter more than schooling due to the 'sheepskin' effect, where returns to education are largest for credentialed levels of education (Hungerford and Solon 1987).
} 
respondents who have not completed primary education. Ultimately, we are interested in the estimates of the coefficients on the interaction terms, which give us the difference in the returns to formality for each education level for indigenous workers, relative to non-indigenous workers.

$\tau_{j}$ represents district fixed-effects included to account for any observed or unobserved district-specific correlates with informality. These could be related to the nature of the local economy wherein agricultural or service-led economies could facilitate informal activities. Additionally, these fixed effects control for possible differences in: the educational quality across districts; capacity of local governments to enforce, monitor or provide registration and documentation necessary to comply with pensions and labor laws; distribution of ethnic populations across districts as some districts could have higher proportion of indigenous, AfroPeruvian or mestizo workers, which could spuriously drive a correlation with the outcome variable.

$\varphi_{i t}$ are age fixed-effects to account for all unobserved characteristics of a person's age that could affect the likelihood of their employment in the informal economy or income. For example, if younger cohorts are more educated, but also more likely to be in the formal sector due to other underlying factors (economic and political stability, trade policies, economic growth, etc.), age fixed effects would capture such economy-wide linear and non-linear trends in the data. This measure also controls for large macroeconomic shocks (e.g. the Shining Path Insurgency) and introduction of new laws in the 1990s, which sought to reduce labor market rigidities.

$X_{i j t}$ represents a vector of individual and household controls. As suggested in the conceptual framework, we control for differences in health, experience, employment, place of residence, type of education and gender. 


\section{Main Results}

Table II presents the results from the difference-in-differences regression, Equation (1). The standalone 'indigenous' coefficient in Column (5) suggests that indigenous individuals with incomplete primary education are 1 percentage point more likely to lack access to a pension than non-indigenous individuals with similar education. Despite this effect being consistently positive in Columns (1) - (5), when controls are included, this effect is measured with a large-enough standard error to render it statistically insignificant even at the $10 \%$ level. Regardless, this coefficient is consistently small relative to the effect of education at other levels.

\section{[Table II Goes Here]}

Primary education is associated with a reduction in the likelihood of informality for nonindigenous individuals of 3.2 percentage points, and this is significant at $1 \%$ across Columns (1) - (5). The inclusion of controls tends to reduce the magnitude of this effect, but this magnitude remains non-trivial. The interaction term of indigenous and primary education implies that indigenous individuals with primary education are on average 2.2 percentage points less likely to be informal than their equally educated non-indigenous peers. However, this result is neither consistently negative nor statistically significant at conventional levels, which is consistent with the third proposed hypothesis: equal returns.

Second, tertiary education is associated with a reduction in the likelihood of informality for non-indigenous individuals of 49 percentage points, as compared to those with incomplete primary education. This is the largest effect estimated and is consistently statistically significant at the $1 \%$ level. The interaction term for indigenous self-identification and tertiary education is not statistically significant. Thus, it indicates that we cannot reject the third hypothesis positing that the returns to tertiary education are similar for indigenous and non-indigenous individuals. 
The real deviation is at the secondary education level. In contrast to the effects of primary and tertiary levels, secondary education is associated with a larger reduction in the likelihood of informality for non-indigenous individuals (20.3 percentage points). This result is consistently significant at $1 \%$, and remains in accordance with notion that higher education is associated with a greater chance of acquiring a formal job. However, the interaction term for self-identification and secondary education supports the first hypothesis positing greater returns for nondiscriminated groups. It implies that, on average, indigenous individuals with secondary education are 6.7 percentage points more likely to be informal than their equally educated non-indigenous peers. This effect is statistically significant at the $1 \%$ level and robust across the staggered control specifications. Our finding indicates that on average, indigenous individuals receive lower returns to secondary education in terms of finding formal employment. For indigenous individuals, secondary education still reduces the likelihood of informality, but by 13.6 percentage points, which is lower than the 20.3 percentage points for non-indigenous individuals. This difference of 6.7 percentage points is greater than the returns to primary education (regardless of ethnicity), and which in Peru constitutes at least 6 years of education.

These findings point toward an 'informality gap' that exists only at secondary levels. Indigenous workers with secondary education face a poverty trap that education cannot ameliorate. Indigenous workers are unable to access employment-related securities as outlined by the ILO (2002), and are likely to secure fewer benefits than they would in the formal sector as compared to the non-indigenous (Gasparini and Tornarolli 2009). Indigenous individuals are disproportionally vulnerable to shocks (Barrientos 2010).

These results can be illustrated graphically and compared to our three hypotheses, where the likelihood of having access to a pension is on the vertical axis and different levels of education 
on the horizontal axis (see Figure 3). ${ }^{18}$ The returns to education for primary and tertiary levels are similar between non-indigenous and indigenous groups, supporting the third hypothesis. However, a gap exists for secondary education, with indigenous groups (dashed line) obtaining fewer benefits at this level relative to non-indigenous groups (solid line), supporting the first hypothesis. Accordingly, Figure 3 resembles a combination of these hypotheses where the curves for indigenous and non-indigenous are close to parallel for primary and tertiary education, but different at secondary education.

\section{Robustness Checks}

\subsection{Productive Informality}

Table III illustrates the different effects of education using productive definitions of formal employment for indigenous and non-indigenous individuals (Perry et al., 2007 and Gasparini and Tornarolli, 2009). As before, the returns to education increase for higher levels of education and remain statistically significant at the $1 \%$ level, although the magnitude of the standalone returns to tertiary education (for non-indigenous and indigenous individuals) increases from 49 to 76 percentage points. Indigenous individuals with secondary education are 4.5 percentage points more likely to be informal than comparably educated non-indigenous individuals. The difference in returns to primary and tertiary education for indigenous individuals relative to non-indigenous

\footnotetext{
${ }^{18}$ Note that Figure 3 plots all estimated coefficients and values, regardless of significance and standard errors. Plotting only statistically significant coefficients illustrates a similar curve.
} 
individuals, both less than 1 percentage point, remain positive, but statistically insignificant. These results further support the idea of a secondary-education informality trap for indigenous workers.

[Table III Goes Here]

\subsection{Indigenous Language}

Table IV illustrates the different effects of education on legalistic informality for indigenous and non-indigenous individuals, using language-based measures: Quechua, Aymara or another Amazonian language as in Trivelli (2005). According to the language-based measure, $21 \%$ of the sample can be classified as indigenous. These results are not substantially different than when we used self-identification as our measure. First, the returns of education to formal employment increase at higher levels of education (for non-indigenous and indigenous individuals). Second, the estimated coefficients per education level have similar magnitudes to self-identification results (see Table II) and remain statistically significant at the $1 \%$ for all specifications. ${ }^{19}$ The estimates imply that on average indigenous individuals with secondary education are 4.3 percentage points more likely to be informal than comparably educated nonindigenous individuals. ${ }^{20}$

[Table IV Goes Here]

\footnotetext{
${ }^{19}$ Primary (5.2 percentage points versus 3.2 in Table II), Secondary (18.9 percentage points versus 20.3 in Table II) and Tertiary (47.3 percentage points and 49 in Table II).

${ }^{20}$ As a final control, we ran similar regressions for productive informality and indigenous language and found the same-sized secondary education informality trap for indigenous workers. See Online Appendix Table AII.
} 


\subsection{Heckman Selection Model}

Econometric analysis based on non-randomly selected samples can yield biased results. One can only observe the type of employment—-formal or informal—based on pension status but we cannot easily observe the justifications for their employment decisions. The social and material conditions for indigenous and non-indigenous individuals are very different, possibly leading each group to make employment decisions differently. If, for example, indigenous individuals have a stronger support system in their homes that allows them to place a lower value on pensions, then they may opt into professions less likely to offer pensions. In order to correct for the possibility of sample selection bias, we implement a two-step Heckman selection model. ${ }^{21}$

Table V shows the results for the Heckman selection model. The coefficient for the interaction term of indigenous and secondary education is shown to be equivalent to 10.9 percentage points and remains statistically significant at the $1 \%$. Furthermore, the selection coefficient (lambda), suggests that the selection effect negatively biases the interaction term on the returns to secondary education for indigenous workers.

[Table V Goes Here]

\section{Explaining the Informality Gap Among High-School Graduates}

Four potential channels may explain the informality gap at the secondary level, but the strongest evidence lies with one of them—quality of secondary education.

\footnotetext{
${ }^{21}$ Our two-step selection model includes a selection equation to estimate the likelihood that an individual will be observed, and a regression equation to estimate the returns to education. See Online Appendix Section A1 for more details.
} 


\subsection{Historical Prejudice}

One possible explanation is historical discrimination that manifests as persistent inequality for indigenous individuals with secondary education. Table VI shows the paper's main result organized by five year age brackets to identify any historical trends on differences in returns to education. Indeed, we observe that the interaction term for secondary education and indigenous greater than 10 percentage-points and statistically significant for middle-aged individuals with (4650 and 51-55 years of age). However, we also observe that this coefficient is consistently positive for all age brackets, albeit not always significant, suggesting that historical discrimination does not adequately explain our main finding. ${ }^{22}$

\section{[Table VI Goes Here]}

\subsection{Sectorial Discrimination or Preference}

Similarly, if certain sectors discriminate disproportionately against a pool of secondaryeducated indigenous individuals we would find difference in returns to education by employment sector or industry. Table VII shows the baseline specification for a set of employment sectors in Peru. Indigenous self-employed individuals and public sector workers experience statistically significant differences in returns to secondary education. ${ }^{23}$ Yet, because it seems that public

\footnotetext{
${ }^{22}$ The exception is the interaction coefficient for 61-65 year olds, which is negative but insignificant.

${ }^{23}$ We also conducted separate regressions using standardized occupational categories adopted by the ILO (ISCO-88) and Peru's adaptation of the codes (CO-95) to separate workers into 7 categories based on required skill. We found that the interaction term for indigenous and
} 
employers discriminate against indigenous workers at all levels, this hypothesis cannot explain the paper's main finding that returns to education are specific to indigenous groups with only secondary education.

\section{[Table VII]}

There is also the potential for sectoral preference based on self-selection. Fields (1990, 2004) and Maloney (2004) argue that many individuals opt for informal self-employment willingly. If indigenous individuals display a preference for informal self-employment over salaried work, and it is most pronounced at secondary education, this preference could explain the estimated differences in returns to education. ${ }^{24}$ However, we don't find support for this selfselection hypothesis in Table VIII.

[Table VIII]

secondary education is consistently positive, but only statistically significant for 'elementary' occupations. Some of these occupations include street vendors, cleaners, food preparation workers and agricultural labourers. This suggests that educated non-indigenous individuals obtain the few elementary occupations that require secondary education and offer pensions. See Online Appendix Section A2.

${ }^{24}$ Adams and Valdivia (1994, 10-11) argue that Andean Peruvians primarily belonging to Quechua and Aymara indigenous groups - often establish cultural autonomy by means of pursuing informal self-employment. 


\subsection{Migration}

Initial theories on informality and segmented labor markets emphasize the role of migration and social capital (Harris and Todaro 1974; Calvó-Armengol and Jackson 2004; Piracha et al. 2013). Where indigenous migrants lack established social networks, they may struggle to find formal employment. ${ }^{25}$

We don't find much support for this hypothesis either. Table IX shows results for a triple interaction model estimating the differences in returns to education for indigenous, non-indigenous migrants, and non-migrants. In this case, migrants are individuals who currently reside in a district other than that of their birth. The results suggest that although indigenous individuals receive on average a penalty for migrating (Indigenous*Migrated) relative to non-indigenous individuals, this effect is not statistically significant for any level of education. The triple interaction term for indigenous migrants with secondary education is negative; these individuals are more likely to find formal employment if they migrate than non-indigenous workers. ${ }^{26}$ Thus, the informality gap is not driven by differences in migration between indigenous and non-indigenous individuals.

[Table IX]

To shed further light on the underlying mechanisms, we test for heterogeneous effects by Peruvian geography, industry classification, rural versus urban locations, male versus female-headed

\footnotetext{
${ }^{25}$ In general, migrants in Peru, both men and women, are relatively young, unmarried and coming from the highland regions (Sánchez Aguilar 2015).

${ }^{26}$ The converse may and is often true: migrants may move to areas where they have an established social network that can facilitate the transition.
} 
households, and public versus private workers. These are provided in Online Appendix Figures 1 and 2, and Tables III to VI.

\subsection{Quality of Schooling}

Differences in labor outcomes for indigenous and non-indigenous individuals may also be explained by differences in the quality of schooling. Indigenous individuals with secondary education may not be offered formal employment if the quality of their education is lower than secondary education for non-indigenous groups. If the quality of secondary schooling in districts with indigenous individuals is manifestly poorer, then returns to education would be different for graduates from these schools.

Detailed historical data on the quality of schooling for secondary-educated Peruvians is not available. However, provincial level data on education expenditures and student-teacher ratios from FONCODES for the year 1999 is available. Data were obtained for the year 1999, the only year for which district level data is available. Previous research has established a positive connection between school resources and student performance (Holmlund, McNally and Viarengo 2010; Haeheland, Rauum and Salvanes 2012).

Table X presents the baseline regression for each quartile of district education spending per student. ${ }^{27}$ The results demonstrate that the differences in the returns to secondary education are large and statistically significant for the bottom three quartiles of district spending per student. The difference in returns to secondary education is largest for the $1^{\text {st }}$ quartile, experiencing the

\footnotetext{
${ }^{27}$ The data on district education expenditures is from 1999, while the data on number of students in a district is from 2001. No data on district-level expenditures after 1999 is available.
} 
lowest spending per student, where indigenous individuals with secondary education are 12.7 percentage points less likely to be formally employed than non-indigenous workers. The magnitude of the coefficient of interest is lower for both the $2^{\text {nd }}$ and $3^{\text {rd }}$ quartile of education spending per student at 8.3 and 8.2 percentage points, respectively. The $4^{\text {th }}$ quartile yields a difference of only 2.3 percentage points, which is insignificant. This input-based view of quality of education offers evidence in favor of the quality of education hypothesis.

[Table X Goes Here]

Furthermore, Table XI explores the relationship between educational quality and the returns to secondary education. It illustrates the baseline regression for quartiles of the number of students per class in the district, where column 1 is the lowest student to teacher ratio and column 4 is the highest student to teacher ratio. Previous literature finds that smaller class sizes allow teachers to spend more time on each student and provide more personalized, higher quality education (Cho, Glewwe and Whitler 2012; Funkouser 2009). ${ }^{28}$ The coefficient for the interaction term is statistically significant and large for columns 3 and 4, in both cases implying a difference in the returns to secondary schooling for indigenous workers greater than 10 percentage points.

[Table XI Goes Here]

It appears that informality trap may be the result of variations in the quality of secondary education provided for each group. Differences in returns to secondary education for indigenous groups occur in districts with fewer resources and larger class sizes-and by extension, lower

\footnotetext{
${ }^{28}$ Researchers have produced numerous studies of class size and educational performance based on statewide educational programs (e.g. STAR in Tennessee, 1985-98, Class Size Reduction in California, 1996-2001, and SAGE in Wisconsin 1996-2001).
} 
quality secondary schools. These differences in resources and quality are less pronounced in primary and tertiary education.

\section{Policy Implications}

Our results suggest that secondary schools serving discriminated groups may require additional resources and carefully targeted policies to help these groups overcome barriers to finding formal employment. Boosting investments and quality in secondary education for the indigenous is thus a policy recommendation stemming from our study.

We conduct a simple back-of-the-envelope calculation on the net wage returns to secondary schooling for indigenous and non-indigenous individuals. In general, we control for the same variables as in our main results, but measure the interaction terms on the outcome variable of yearly income in local currency. ${ }^{29} \mathrm{We}$ calculate the net present value of the stream of future income for primary and secondary education at different interest rates for each ethnicity. Then, we calculate the net difference between the expected lifetime stream between secondary and primary education for each group.

Figure 4 illustrates the different net returns to secondary education for indigenous and nonindigenous. Non-indigenous workers find it beneficial to pursue secondary education until an interest rate of 1.5 percent, at which point they would be better off foregoing secondary education. In contrast, indigenous workers face wholly negative returns to secondary education at all interest

\footnotetext{
${ }^{29}$ Income was self-reported on a monthly, bi-weekly, weekly and daily basis. Figures were converted to yearly figures to minimize variation. Assumptions required for the calculations are provided in Online Appendix Section A4.
} 
rates. Although these results are a simplified representation of averages, they suggest that the overall returns to secondary education are small in Peru, but that the wage and employment returns to only completing secondary education for indigenous individuals is considerably lower. ${ }^{30}$

[Figure 4 Goes Here]

\section{Conclusion}

We demonstrate that education can be a powerful tool to empower discriminated groups to resist labor-market discrimination, but not at every level. Increases in levels of education lead to non-linear increases in the likelihood of formal employment. At the primary and tertiary level, indigenous and non-indigenous face similar chances of finding formal employment. At the secondary level, in contrast, the returns to education are lower for non-indigenous workers. This finding is robust to numerous specifications.

We also find that this informality trap across indigenous groups with only secondary education cannot be fully explained by historical discrimination, migration, or industry-specific variables. Instead, we find that past differences in the quality of education matters the most: secondary education for indigenous groups appears to be of lower quality than for non-indigenous groups. The overall consequence is a possible development trap for indigenous workers, even those who have succeeded at attaining secondary education.

Latin America has made huge inroads in universalizing education at the secondary level. But it now faces the challenge of universalizing the quality of education at the secondary level.

\footnotetext{
${ }^{30}$ Note that the interaction term for indigenous and secondary education approaches significance but is measured with sufficient error as to render the coefficient insignificant at the $10 \%$ level.
} 
The case of Peru suggests that, in trying to reach the "missing middle", more needs to be done to improve the quality of secondary education to reduce the informality burden on marginalized groups.

\section{REFERENCES}

Adams, Norma., and Néstor. Valdivia. 1994. Los otros empresarios: etica de migrantes y formación de empresas en Lima. Lima: Instituto de Estudios Peruanos.

Barrientos, A. 2010. "Social Protection and Poverty." Social Policy and Development 42. United Nations Research Institute for Social Development.

http://www.unrisd.org/80256B3C005BCCF9/httpNetITFramePDF?ReadForm\&parentuni $\mathrm{d}=973 \mathrm{~B} 0 \mathrm{~F} 57 \mathrm{CA}$ 78D834C12576DB003BE255\&parentdoctype=paper\&netitpath=80256B 3C005BCCF9/(httpAuxPages)/973B0F57CA78D834C12576DB003BE255/\$file/Barrient os-pp.pdf.

Barrientos, Armando. 2011. "Social Protection and Poverty." International Journal of Social Welfare 20 (3): 240-49. doi:10.1111/j.1468-2397.2011.00783.x. 
Becker, Gary S. 1964. Human Capital; a Theoretical and Empirical Analysis, with Special Reference to Education. National Bureau of Economic Research. General Series: No. 80. New York: Columbia University Press.

Bernheim, B. Douglas, Debraj Ray, and Şevin Yeltekin. 2015. "Poverty and Self-Control." Econometrica 83 (5): 1877-1911. doi:10.3982/ECTA11374.

Bertrand, Marianne, and Sendhil Mullainathan. 2004. "Are Emily and Greg More Employable than Lakisha and Jamal? A Field Experiment on Labor Market Discrimination.” The American Economic Review, no. 4: 991.

Bloch, Farrell E., and Sharon P. Smith. 1977. "Human Capital and Labor Market Employment." Journal of Human Resources 12 (4): 550-60.

Cadena, Marisol de la. 2000. Indigenous Mestizos: The Politics of Race and Culture in Cuzco, Peru, 1919-1991. Durham: Duke University Press.

Calvó-Armengol, Antoni, and Matthew O. Jackson. 2004. "The Effects of Social Networks on Employment and Inequality." The American Economic Review 94 (3): 426.

Canavire-Bacarreza, Gustavo. 2008. "Analyzing Wage Gaps for Indigenous in Informal and Formal Labor Markets in Latinamerica: The Case of Bolivia, Brazil, Ecuador, Guatemala, Nicarague and Perú.” Institute for the Study of Labor.

Carnoy, M. 1996. "Race, Gender, and the Role of Education in Earnings Inequality: An Introduction." Economics of Education Review 15 (3): 207-12.

Charles, K., and J. Guryan. 2011. "Studying Discrimination: Fundamental Challenges and Recent Progress.” Annual Review of Economics 3: 479-512.

Chen, Martha, Joann Vanek, and James Heintz. 2006. "Informality, Gender and Poverty: A Global Picture." Economic and Political Weekly, no. 21: 2131. 
Chiswick, B. 1988. "Differences in Education and Earnings Accross Racial and Ethnic Groups: Tates, Discrimination, and Invstments in Child Quality." Quarterly Journal of Economics 103 (3): 571-96.

Cho, Hyunkuk, Paul Glewwe, and Melissa Whitler. 2012. "Do Reductions in Class Size Raise Students' Test Scores? Evidence from Population Variation in Minnesota's Elementary Schools." Economics of Education Review 31 (3): 77-95. doi:10.1016/j.econedurev.2012.01.004.

Corrales, Javier. 2005. "Political Obstacles to Expanding and Improving Schooling in Developing Countries." In Educating All Children: A Global Agenda, edited by Joel E. Cohen and Martin B Malin. Cambridge, MA: The MIT Press.

Cunningham, Wendy, and Joyce Jacobsen. 2008. "Earnings Inequality within and across Gender, Racial, and Ethnic Groups in Four Latin American Countries.” World Bank Research Working Paper No. 4591. Washington, DC: The World Bank.

Dabos, M., and G. Psacharopoulos. 1991. "An Analysis of the Sources of Earnings Variation among Brazilian Males.” Economics of Education Review 10 (4): 359-77.

Datta, Saugato, and Vikram Pathania. 2016. "For Whom Does the Phone (not) Ring?: Discrimination in the Rental Housing Market in Delhi, India.” WIDER Working Paper 2016/55. Helsinki: UNI-WIDER. https://www.wider.unu.edu/publication/whom-doesphone-not-ring.

Deshpande, Ashwini, and Smriti Sharma. 2015. "Disadvantage and Discrimination in SelfEmployment: Caste Gaps in Earnings in Indian Small Businesses.” WIDER Working Paper 2015/067. Helsinki: UNI-WIDER. 
https://www.wider.unu.edu/publication/disadvantage-and-discrimination-selfemployment.

ENAHO. 2010. Encuesta Nacional de Hogares sobre Condiciones de Vida y Pobreza. Instituto Nacional de Estadística e Informática.

Engerman, Stanley L, and Kenneth Lee Sokoloff. 2002. "Factor Endowments, Inequality, and Paths of Development among New World Economies." Economía, no. 1: 41.

Fryer, Jr. Roland G., Devah Pager, and Jörg L. Spenkuch. 2013. "Racial Disparities in Job Finding and Offered Wages." Journal of Law and Economics, no. 3: 633.

Fryer, R. 2010. "Racial Inequality in the 21st Century: The Declining Significance of Discrimination.” In Handbook of Labor Economics, edited by O Ashenfelter and D Card, 1st ed. Vol. 4B. North Holland.

http://scholar.harvard.edu/files/fryer/files/racial_inequality_in_the_21st_century_the_dec lining_significance_of_discrimination.pdf?m=1360041492.

FONCODES. 2001. Fondo de Cooperación para el Desarrollo Social. Ministerio de Desarrollo e Inclusión Social.

Funkhouser, Edward. 2009. "The Effect of Kindergarten Classroom Size Reduction on Second Grade Student Achievement: Evidence from California.” Economics of Education Review 28 (3): 403-14.

Galarza, Francisco B., and Gustavo Yamada. 2014. "Labor Market Discrimination in Lima, Peru: Evidence from a Field Experiment." World Development 58 (June): 83-94. doi:http://www.sciencedirect.com/science/journal/0305750X.

Galarza, Francisco, Liuba Kogan, and Gustavo Yamada. 2012. "Detectando discriminación sexual y racial en el mercado laboral de Lima." In Discriminación en el Perú: 
Exploraciones en el Estado, la empresa y el mercado laboral, 103. Lima: Universidad del Pacífico.

Galiani, Sebastian, and Federico Weinschelbaum. 2012. "Modeling Informality Formally: Households and Firms." Economic Inquiry 50 (3): 821-38. doi:10.1111/\%28ISSN\%291465-7295/issues.

Gasparini, Leonardo, and Leopoldo Tornarolli. 2009. "Labor Informality in Latin America and the Caribbean: Patterns and Trends from Household Survey Microdata." Desarrollo $Y$ Sociedad, no. 63: 13-80.

doi:http://economia.uniandes.edu.co/investigaciones_y_publicaciones/CEDE/Publicacion es/Revista_Desarrollo_y_Sociedad.

Haegeland, Torbjorn, Oddbjorn Raaum, and Kjell G. Salvanes. 2012. "Pennies from Heaven? Using Exogenous Tax Variation to Identify Effects of School Resources on Pupil Achievement." Economics of Education Review 31 (5): 601-14. doi:http://www.sciencedirect.com/science/journal/02727757.

Hall, Gillette, and Harry Anthony Patrinos. 2006. Indigenous Peoples, Poverty, and Human Development in Latin America : New York: Palgrave Macmillan.

Harris, John R., and Michael P. Todaro. 1970. "Migration, Unemployment and Development: A Two-Sector Analysis." American Economic Review 60 (1): 126-42.

Hart, Keith. 1973. "Informal Income Opportunities and Urban Employment in Ghana." The Journal of Modern African Studies, no. 1: 61.

Holmlund, Helena, Sandra McNally, and Martina Viarengo. 2010. "Does Money Matter for Schools?" Economics of Education Review 29 (6): 1154-64. 
ILO. 2002. "Decent Work and the Informal Economy.” VI. International Labour Organization (ILO). http://www.ilo.org/public/english/standards/relm/ilc/ilc90/pdf/rep-vi.pdf. . 2013. Measuring Informality: A Statistical Manual on the Informal Sector and Informal Employment. http://www.ilo.org/global/publications/ilo-bookstore/orderonline/books/WCMS_222979/lang--en/index.htm.

Jensen, Robert. 2010. "The (Perceived) Returns to Education and the Demand for Schooling." The Quarterly Journal of Economics 125 (2): 515.

Klaauw, Wilbert van der, and Kenneth I. Wolpin. 2008. "Social Security and the Retirement and Savings Behavior of Low-Income Households." Journal of Econometrics, The use of econometrics in informing public policy makers, 145 (1-2): 21-42. doi:10.1016/j.jeconom.2008.05.004.

Lapeyre, Frederic, Sriani Ameratunga, and Silvia Possenti. 2012. “Addressing Informality for Rural Development.” Rural Policy Briefs. Rural Development Through Decent Work. International Labour Organization (ILO). http://www.ilo.org/wcmsp5/groups/public/--ed_emp/documents/publication/wcms_182737.pdf.

López-Calva, Luis Felipe, and Nora Lustig. 2010. Declining Inequality in Latin America : A Decade of Progress? Washington D.C.: Brookings Institution Press.

Martins, Pedro, and Terry McKinley. 2011. "Social Inclusiveness in Asia’s Middle Income Countries." Overseas Development Institute (ODI). http://www.odi.org/sites/odi.org.uk/files/odi-assets/publications-opinion-files/7522.pdf.

Méndez, C. 1996. "Incas Sí, Indios No: Notes on Peruvian Creole Nationalism and Its Contemporary Crisis.” Journal of Latin American Studies 28 (1): 197-225. 
Mincer, J. 1974. Schooling, Experience and Earnings. New York: Columbia University Press for the National Bureau of Economic Research.

Mincer, Jacob. 1989. Education and Unemployment. Technical Paper: No. 11. New

York/Washington DC: National Center on Education and Employment ; U.S. Dept. of

Education, Office of Educational Research and Improvement.

Montgomery, James D. 1991. "Social Networks and Labor-Market Outcomes: Toward an

Economic Analysis." The American Economic Review, no. 5: 1408.

Munshi, Kaivan. 2003. "Networks in the Modern Economy: Mexican Migrants in the U.S. Labor Market." Quarterly Journal of Economics 118 (2): 549-99.

doi:10.1162/003355303321675455.

Neal, Derek A., and William R. Johnson. 1996. "The Role of Premarket Factors in Black-White Wage Differences." Journal of Political Economy, no. 5: 869.

Ñopo, Hugo. 2012. New Century, Old Disparities : Gender and Ethnic Earnings Gaps in Latin America and the Caribbean. Latin American Development Forum Series. Washington, DC: nter-American Development Bank and the World Bank.

ODI. 2007. "Rural Employment and Migration: In Search of Decent Work. New Thinking of Rural Employment Is Needed to Create More and Better Rural Jobs.” Briefing Paper No. 27. London: Overseas Development Institute (ODI). http://www.odi.org/sites/odi.org.uk/files/odi-assets/publications-opinion-files/6.pdf. Oficina de Normalización Previsional (ONP). 2016. Pensiones en Perú y ONP: Sistema previsional y sus actores. Lima. Retrieved from https://www.onp.gob.pe/pensiones_peru_onp/sistema_previsional. 
Pager, Devah. 2007. "The Use of Field Experiments for Studies of Employment Discrimination: Contributions, Critiques, and Directions for the Future." Annals of the American Academy of Political and Social Science 609 (1): 104-33.

Pager, Devah, Bruce Western, and Bart Bonikowski. 2009. "Discrimination in a Low-Wage Labor Market: A Field Experiment.” American Sociological Review 74 (5): 777-800. Peredo, Ana Maria. 2007. “The Road Less Travelled in Peru.” In International Handbook of Research on Indigenous Entrepreneurship, edited by Leo-Paul Dana and Robert B. Anderson, 426-44. Cheltenham/Northampton: Edward Elgar Publishing Limited. Peredo, Ana Maria, and Murdith McLean. 2010. "Indigenous Development and the Cultural Captivity of Entrepreneurship.” Business \& Society 20 (10): 1-29. doi:10.1177/0007650309356201.

Perry, Guillermo, William Maloney, Oscar Arias, Pablo Fajnzylber, Andrew Mason, and Jaime Saavedra-Chanduvi. 2007. Informality : Exit and Exclusion. World Bank Latin American and Caribbean Studies. Washington, DC: World Bank.

Piracha, Matloob, Massimiliano Tani, and Matias Vaira Lucero. 2013. "Social Capital and Immigrants’ Labour Market Performance.” Papers in Regional Science 95 (S1): S107_ 26. doi:doi:10.1111/pirs.12116.

Psacharopoulos, George. 1972. "Rates of Return on Investment in Education around the World." Comparative Education 16 (1): 54-67.

Psacharopoulos, George, and Harry Anthony Patrinos. 2004. "Returns to Investment in Education: A Further Update.” Education Economics 12 (2): 111-34. 
Saavedra, Jaime, and Alberto Chong. 1999. "Structural Reform, Institutions and Earnings:

Evidence from the Formal and Informal Sectors..." Journal of Development Studies 35 (4): 95.

Soto, Hernando de. 1989. The Other Path: The Invisible Revolution in the Third World. New York: Harper \& Row.

Thorp, Rosemary, and Maritza Paredes. 2010. Ethnicity and the Persistence of Inequality: The Case of Peru [electronic Version]. Conflict, Inequality and Ethnicity. New York: Palgrave Macmillan.

Trivelli, Carolina. 2005. "Una Mirada Cuantitativa a La Situacion de Pobreza de Los Hogares Indigenas En E1 Peru.” Economía, no. 55-66.

UNDP. 2013. "Challenges of the Middle Income Countries: Seoul Debates.” Seoul: South Korea: United Nations Development Programme.

World Bank. 2016. World Development Indicators. Retrieved from http://data.worldbank.org/data-catalog/world-development-indicators. 
Table I Descriptive Statistics disaggregated by ethnicity

\begin{tabular}{|c|c|c|c|c|c|c|c|c|c|c|}
\hline & \multicolumn{3}{|c|}{ Total Sample } & \multicolumn{3}{|c|}{ Indigenous } & \multicolumn{3}{|c|}{ Non-Indigenous } & \multirow[t]{2}{*}{ Difference } \\
\hline & Mean & $\begin{array}{c}\text { Standard } \\
\text { Deviatio } \\
n\end{array}$ & $\begin{array}{c}\text { Sampl } \\
\text { e }\end{array}$ & Mean & $\begin{array}{c}\text { Standard } \\
\text { Deviatio } \\
\mathrm{n}\end{array}$ & $\begin{array}{c}\text { Sampl } \\
\mathrm{e}\end{array}$ & Mean & $\begin{array}{c}\text { Standard } \\
\text { Deviatio } \\
\mathrm{n}\end{array}$ & $\begin{array}{c}\text { Sampl } \\
\mathrm{e}\end{array}$ & \\
\hline \multicolumn{11}{|l|}{ Informality } \\
\hline No pension (legalistic) & 0.714 & 0.452 & 20,799 & 0.799 & 0.400 & 7,482 & 0.666 & 0.472 & 13,317 & $0.133 * * *$ \\
\hline Productive Informality & 0.724 & 0.447 & 14,630 & 0.799 & 0.401 & 5,681 & 0.676 & 0.468 & 8,949 & $0.123 * * *$ \\
\hline \multicolumn{11}{|l|}{ Education } \\
\hline Less than Primary & 0.328 & 0.470 & 20,535 & 0.454 & 0.498 & 7,432 & 0.257 & 0.437 & 13,103 & $0.198 * * *$ \\
\hline Primary & 0.302 & 0.459 & 20,535 & 0.293 & 0.455 & 7,432 & 0.307 & 0.461 & 13,103 & $-0.013 * * *$ \\
\hline Secondary & 0.242 & 0.428 & 20,535 & 0.177 & 0.382 & 7,432 & 0.278 & 0.448 & 13,103 & $-0.101 * * *$ \\
\hline Tertiary & 0.128 & 0.334 & 20,535 & 0.075 & 0.264 & 7,432 & 0.158 & 0.365 & 13,103 & $-0.083 * * *$ \\
\hline Public School & 0.899 & 0.302 & 18,751 & 0.936 & 0.244 & 6,228 & 0.880 & 0.325 & 12,523 & $0.057 * * *$ \\
\hline \multicolumn{11}{|c|}{ Individual Characteristics } \\
\hline Indigenous & 0.640 & - & 20,800 & - & - & 7,482 & - & - & 13,318 & \\
\hline Female & 0.490 & 0.500 & 20,800 & 0.463 & 0.499 & 7,482 & 0.506 & 0.500 & 13,318 & $-0.043 * * *$ \\
\hline Migrated & 0.447 & 0.497 & 20,800 & 0.539 & 0.498 & 7,482 & 0.395 & 0.489 & 13,318 & $0.144 * * *$ \\
\hline Chronic Illness & 0.485 & 0.500 & 20,798 & 0.437 & 0.496 & 7,482 & 0.512 & 0.500 & 13,316 & $-0.075 * * *$ \\
\hline Rural & 0.406 & 0.491 & 20,800 & 0.563 & 0.496 & 7,482 & 0.318 & 0.466 & 13,318 & $0.245 * * *$ \\
\hline Married & 0.418 & 0.493 & 20,800 & 0.417 & 0.493 & 7,482 & 0.418 & 0.493 & 13,318 & -0.001 \\
\hline Age & 49.357 & 15.610 & 20,800 & 50.043 & 16.054 & & 48.972 & 15.341 & & $1.071 * * *$ \\
\hline \multicolumn{11}{|c|}{ Household Characteristics } \\
\hline Bedrooms & 3.317 & 1.79 & 20,377 & 3.115 & 1.77 & 7432 & 3.434 & 1.796 & 12,945 & $0.319 * * *$ \\
\hline Sanitation & 0.818 & 0.386 & 20,800 & 0.768 & 0.422 & 7482 & 0.846 & 0.361 & 13,318 & $0.078 * * *$ \\
\hline Household Size & 4.411 & 2.335 & 20,800 & 4.294 & 2.398 & 7482 & 4.477 & 2.296 & 13,318 & $0.183 * * *$ \\
\hline Internet Access & 0.0739 & 0.27 & 20,800 & 0.0294 & 0.169 & 7482 & 0.107 & 0.4 & 13,318 & $0.078 * * *$ \\
\hline Electricity & 0.805 & 0.396 & 20,800 & 0.749 & 0.434 & 7482 & 0.837 & 0.369 & 13,318 & $0.089 * * *$ \\
\hline Piped Water & 0.668 & 0.471 & 20,800 & 0.576 & 0.494 & 7482 & 0.72 & 0.449 & 13,318 & $0.144 * * *$ \\
\hline Landline & 0.1989 & 0.398 & 20,800 & 0.0805 & 0.272 & 7482 & 0.264 & 0.441 & 13,318 & $0.183 * * *$ \\
\hline
\end{tabular}




\begin{tabular}{|c|c|c|c|c|c|c|c|c|c|c|}
\hline Mobile & 0.681 & 0.466 & 20,800 & 0.583 & 0.493 & 7482 & 0.737 & 0.44 & 13,318 & $0.155 * * *$ \\
\hline \multicolumn{11}{|l|}{ Employment } \\
\hline $\begin{array}{l}\text { Public Employment } \\
\text { Workplace is }\end{array}$ & 0.356 & 0.479 & 4,809 & 0.330 & 0.470 & 1,429 & 0.367 & 0.482 & 3,380 & $-0.037 * * *$ \\
\hline Registered & 0.104 & 0.306 & 13,913 & 0.066 & 0.248 & 5,475 & 0.129 & 0.336 & 8,438 & $-0.064 * * *$ \\
\hline Workers at place of & 1000.99 & 2936.99 & & 734.02 & 2559.68 & & 1165.97 & 3136.40 & & -431.945 \\
\hline work & 6 & 3 & 17,487 & 8 & 3 & 6,679 & 3 & 3 & 10,808 & $* * *$ \\
\hline & 1032.99 & 1065.58 & & 888.73 & & & 1092.22 & 1158.23 & & -203.486 \\
\hline Monthly Income & 5 & 9 & 4,920 & 5 & 777.735 & 1,432 & 1 & 3 & 3,488 & $* * *$ \\
\hline Self Employed & 0.529 & 0.499 & 17,591 & 0.590 & 0.492 & 6,688 & 0.492 & 0.500 & 10,903 & $0.098 * * *$ \\
\hline $\begin{array}{l}\text { Works at } \\
\text { microenterprise }\end{array}$ & 0.832 & 0.374 & 15,833 & 0.853 & 0.354 & 6,212 & 0.819 & 0.385 & 9,621 & $0.034 * * *$ \\
\hline Unemployed & 0.201 & 0.400 & 20,799 & 0.145 & 0.353 & 7,482 & 0.232 & 0.422 & 13,317 & $-0.086 * * *$ \\
\hline Secondary Employment & 0.247 & 0.431 & 17,591 & 0.254 & 0.435 & 6,688 & 0.243 & 0.429 & 10,903 & $0.011 * * *$ \\
\hline Tenure & 12.127 & 13.423 & 17,589 & 13.739 & 14.237 & 6686 & 11.138 & 12.8 & 10903 & $2.601 * * *$ \\
\hline
\end{tabular}


Figure 3: Estimated returns to education for indigenous and non-indigenous workers, by completed education level

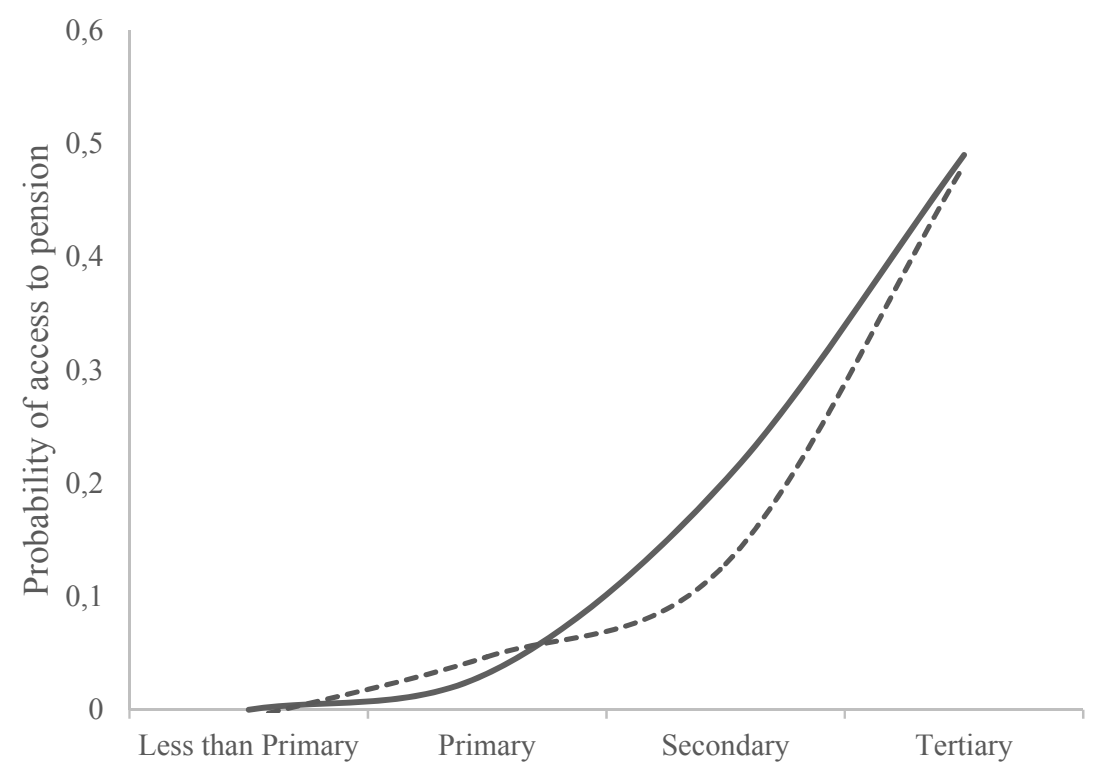

Source: Author's own elaboration using ENAHO (2010).

Note: Only the interaction term for indigenous individuals with secondary education is statistically significant 
Table II Returns to education and pensionable employment for indigenous and nonindigenous workers

\begin{tabular}{|c|c|c|c|c|c|}
\hline $\begin{array}{l}\text { Legalistic } \\
\text { Informality } \\
(\text { No Pension }=1) \\
\end{array}$ & (1) & (2) & (3) & (4) & $(5)$ \\
\hline Indigenous & $\begin{array}{c}0.0312 * * * \\
(0.00838)\end{array}$ & $\begin{array}{c}0.00788 \\
(0.00935)\end{array}$ & $\begin{array}{l}0.00788 \\
(0.0111)\end{array}$ & $\begin{array}{l}0.00389 \\
(0.0109)\end{array}$ & $\begin{array}{l}0.00734 \\
(0.0141)\end{array}$ \\
\hline Primary & $\begin{array}{c}-0.0826 * * * \\
(0.00851)\end{array}$ & $\begin{array}{c}-0.0236^{* * *} \\
(0.00899)\end{array}$ & $\begin{array}{l}-0.0236^{* *} \\
(0.00940)\end{array}$ & $\begin{array}{c}-0.0444 * * * \\
(0.00941)\end{array}$ & $\begin{array}{c}-0.0319 * * * \\
(0.0100)\end{array}$ \\
\hline Secondary & $\begin{array}{c}-0.298 * * * \\
(0.0107)\end{array}$ & $\begin{array}{c}-0.193^{* * *} \\
(0.0125)\end{array}$ & $\begin{array}{c}-0.193 * * * \\
(0.0140)\end{array}$ & $\begin{array}{c}-0.233^{* * *} * \\
(0.0139)\end{array}$ & $\begin{array}{c}-0.203 * * * \\
(0.0147)\end{array}$ \\
\hline Tertiary & $\begin{array}{c}-0.619 * * * \\
(0.0119)\end{array}$ & $\begin{array}{c}-0.475 * * * \\
(0.0153)\end{array}$ & $\begin{array}{c}-0.475 * * * \\
(0.0180)\end{array}$ & $\begin{array}{c}-0.517 * * * \\
(0.0180)\end{array}$ & $\begin{array}{c}-0.490 * * * \\
(0.0196)\end{array}$ \\
\hline$I^{*}$ Primary & $\begin{array}{l}-0.0105 \\
(0.0131)\end{array}$ & $\begin{array}{l}-0.0115 \\
(0.0135)\end{array}$ & $\begin{array}{l}-0.0115 \\
(0.0134)\end{array}$ & $\begin{array}{l}-0.0157 \\
(0.0134)\end{array}$ & $\begin{array}{l}-0.0223 \\
(0.0146)\end{array}$ \\
\hline$I^{*}$ Secondary & $\begin{array}{c}0.0865 * * * \\
(0.0171)\end{array}$ & $\begin{array}{c}0.0891 * * * \\
(0.0180)\end{array}$ & $\begin{array}{c}0.0891 * * * \\
(0.0205)\end{array}$ & $\begin{array}{c}0.0877 * * * \\
(0.0203)\end{array}$ & $\begin{array}{c}0.0668 * * * \\
(0.0210)\end{array}$ \\
\hline $\mathrm{I}^{*}$ Tertiary & $\begin{array}{c}0.0254 \\
(0.0242)\end{array}$ & $\begin{array}{c}0.0219 \\
(0.0261)\end{array}$ & $\begin{array}{c}0.0219 \\
(0.0283)\end{array}$ & $\begin{array}{c}0.0244 \\
(0.0278)\end{array}$ & $\begin{array}{l}0.00137 \\
(0.0300)\end{array}$ \\
\hline Public School & & $\begin{array}{c}-0.0305^{* *} \\
(0.0138)\end{array}$ & $\begin{array}{c}-0.0305^{* *} \\
(0.0127)\end{array}$ & $\begin{array}{l}-0.0206 \\
(0.0128)\end{array}$ & $\begin{array}{l}-0.0248^{*} \\
(0.0133)\end{array}$ \\
\hline Rural & & $\begin{array}{c}0.0910 * * * \\
(0.0106)\end{array}$ & $\begin{array}{c}0.0910 * * * \\
(0.0132)\end{array}$ & $\begin{array}{c}0.0821 * * * \\
(0.0129)\end{array}$ & $\begin{array}{c}0.0380^{* * * *} \\
(0.0141)\end{array}$ \\
\hline Female & & $\begin{array}{l}0.202 * * * \\
(0.00730)\end{array}$ & $\begin{array}{l}0.202 * * * \\
(0.00936)\end{array}$ & $\begin{array}{l}0.194 * * * \\
(0.00930)\end{array}$ & $\begin{array}{l}0.207 * * * \\
(0.00970)\end{array}$ \\
\hline Married & & $\begin{array}{c}-0.0296 * * * \\
(0.00667)\end{array}$ & $\begin{array}{c}-0.0296 * * * \\
(0.00677)\end{array}$ & $\begin{array}{l}-0.0171^{* *} \\
(0.00689)\end{array}$ & $\begin{array}{l}-0.00944 \\
(0.00692)\end{array}$ \\
\hline Chronic Illness & & $\begin{array}{c}-0.0368 * * * \\
(0.00638)\end{array}$ & $\begin{array}{c}-0.0368 * * * \\
(0.00652)\end{array}$ & $\begin{array}{l}-0.0116^{*} \\
(0.00675)\end{array}$ & $\begin{array}{l}-0.0143 * * \\
(0.00703)\end{array}$ \\
\hline Migrated & & $\begin{array}{c}0.0240 * * * \\
(0.00739)\end{array}$ & $\begin{array}{c}0.0240 * * * \\
(0.00856)\end{array}$ & $\begin{array}{l}0.0187 * * \\
(0.00861)\end{array}$ & $\begin{array}{c}0.00463 \\
(0.00843)\end{array}$ \\
\hline Tenure & & $\begin{array}{c}0.00104 * * * \\
(0.000269)\end{array}$ & $\begin{array}{l}0.00104 * * * \\
(0.000312)\end{array}$ & $\begin{array}{c}0.00283 * * * \\
(0.000360)\end{array}$ & $\begin{array}{c}0.00253 * * * \\
(0.000322)\end{array}$ \\
\hline Bedrooms & & $\begin{array}{c}-0.0109 * * * \\
(0.00204)\end{array}$ & $\begin{array}{c}-0.0109 * * * \\
(0.00209)\end{array}$ & $\begin{array}{c}-0.00571 * * * \\
(0.00207)\end{array}$ & $\begin{array}{c}-0.00842 * * * \\
(0.00212)\end{array}$ \\
\hline Electricity & & $\begin{array}{c}-0.0569 * * * \\
(0.00869)\end{array}$ & $\begin{array}{c}-0.0569 * * * \\
(0.00881)\end{array}$ & $\begin{array}{c}-0.0516 * * * \\
(0.00866)\end{array}$ & $\begin{array}{c}-0.0380 * * * \\
(0.00947)\end{array}$ \\
\hline Piped Water & & $\begin{array}{l}-0.0182 * * \\
(0.00866)\end{array}$ & $\begin{array}{c}-0.0182 * * \\
(0.00912)\end{array}$ & $\begin{array}{l}-0.0126 \\
(0.00905)\end{array}$ & $\begin{array}{l}-0.0240 * * \\
(0.00979)\end{array}$ \\
\hline Landline & & $\begin{array}{c}-0.0822 * * * \\
(0.0114)\end{array}$ & $\begin{array}{c}-0.0822 * * * \\
(0.0131)\end{array}$ & $\begin{array}{c}-0.0624 * * * \\
(0.0130)\end{array}$ & $\begin{array}{c}-0.0588 * * * \\
(0.0128)\end{array}$ \\
\hline Mobile & & $\begin{array}{c}-0.0513 * * * \\
(0.00737)\end{array}$ & $\begin{array}{c}-0.0513 * * * \\
(0.00818)\end{array}$ & $\begin{array}{c}-0.0578 * * * \\
(0.00806)\end{array}$ & $\begin{array}{c}-0.0412 * * * \\
(0.00804)\end{array}$ \\
\hline Internet & & $\begin{array}{c}-0.0490 * * * \\
(0.0154)\end{array}$ & $\begin{array}{c}-0.0490 * * * \\
(0.0183)\end{array}$ & $\begin{array}{c}-0.0554 * * * \\
(0.0186)\end{array}$ & $\begin{array}{c}-0.0399 * * \\
(0.0181)\end{array}$ \\
\hline
\end{tabular}


Sanitation

$\begin{array}{ccccc} & -0.0118 & -0.0118 & -0.0130 & -0.0149 \\ & (0.00824) & (0.00949) & (0.00946) & (0.00938) \\ & 0.00882 * * * & 0.00882 * * * & 0.00633 * * * & 0.00264 * \\ & (0.00138) & (0.00152) & (0.00157) & (0.00157) \\ 0.883 * * * & 0.858 * * * & 0.858 * * * & 0.529 * * * & 1.031 * * * \\ (0.00667) & (0.0210) & (0.0245) & (0.179) & (0.142)\end{array}$

\section{Controls}

Basic

District Cluster

X

$\mathbf{X}$
$\mathbf{X}$

$\begin{array}{ll}\mathbf{X} & \mathbf{X} \\ \mathbf{X} & \mathbf{X} \\ \mathbf{X} & \mathbf{X} \\ & \mathbf{X}\end{array}$

District Fixed

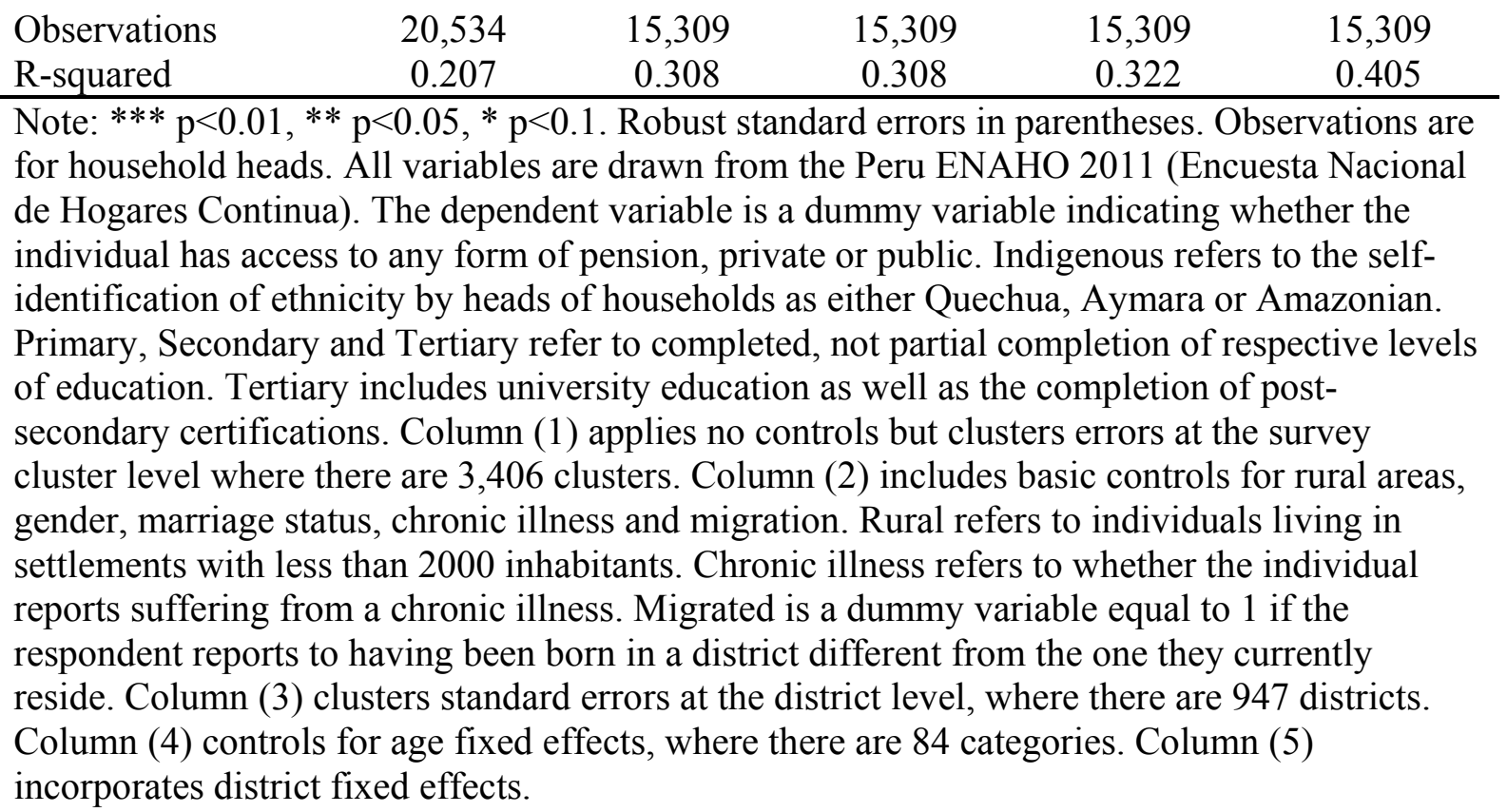


Table III Returns to education and productive informality for indigenous and non-indigenous workers

\begin{tabular}{|c|c|c|c|c|c|}
\hline $\begin{array}{l}\text { Productive } \\
\text { Informality } \\
\qquad(=1)\end{array}$ & $(1)$ & (2) & (3) & (4) & $(5)$ \\
\hline Indigenous & $\begin{array}{c}-0.00176 \\
(0.00831) \\
-\end{array}$ & $\begin{array}{c}-0.000861 \\
(0.0102)\end{array}$ & $\begin{array}{c}-0.000861 \\
(0.00999)\end{array}$ & $\begin{array}{c}0.00244 \\
(0.00995)\end{array}$ & $\begin{array}{l}-0.0214 \\
(0.0135)\end{array}$ \\
\hline Primary & $\begin{array}{c}0.0706 * * * \\
(0.00892)\end{array}$ & $\begin{array}{c}-0.0426 * * * \\
(0.00953)\end{array}$ & $\begin{array}{c}-0.0426 * * * \\
(0.00971)\end{array}$ & $\begin{array}{c}-0.0343 * * * \\
(0.00960)\end{array}$ & $\begin{array}{c}-0.0240 * * \\
(0.0101)\end{array}$ \\
\hline Secondary & $\begin{array}{c}-0.237 * * * \\
(0.0118)\end{array}$ & $\begin{array}{c}-0.179 * * * \\
(0.0131)\end{array}$ & $\begin{array}{c}-0.179 * * * \\
(0.0143)\end{array}$ & $\begin{array}{c}-0.168 * * * \\
(0.0145)\end{array}$ & $\begin{array}{c}-0.166 * * * \\
(0.0152)\end{array}$ \\
\hline Tertiary & $\begin{array}{c}-0.867 * * * \\
(0.00823)\end{array}$ & $\begin{array}{c}-0.776^{* * *} \\
(0.0118)\end{array}$ & $\begin{array}{c}-0.776 * * * \\
(0.0112)\end{array}$ & $\begin{array}{c}-0.761 * * * \\
(0.0116)\end{array}$ & $\begin{array}{c}-0.762 * * * \\
(0.0130)\end{array}$ \\
\hline$I^{*}$ Primary & $\begin{array}{c}0.0164 \\
(0.0136)\end{array}$ & $\begin{array}{c}0.0123 \\
(0.0145)\end{array}$ & $\begin{array}{c}0.0123 \\
(0.0149)\end{array}$ & $\begin{array}{l}0.00961 \\
(0.0149)\end{array}$ & $\begin{array}{l}0.00486 \\
(0.0162)\end{array}$ \\
\hline$I^{*}$ Secondary & $\begin{array}{c}0.0501 * * \\
(0.0196)\end{array}$ & $\begin{array}{c}0.0419^{* *} \\
(0.0203)\end{array}$ & $\begin{array}{c}0.0419 * * \\
(0.0208)\end{array}$ & $\begin{array}{l}0.0374 * \\
(0.0207)\end{array}$ & $\begin{array}{c}0.0452 * * \\
(0.0222)\end{array}$ \\
\hline $\mathrm{I}^{*}$ Tertiary & $\begin{array}{l}0.00224 \\
(0.0143)\end{array}$ & $\begin{array}{l}-0.00943 \\
(0.0164)\end{array}$ & $\begin{array}{r}-0.00943 \\
(0.0163)\end{array}$ & $\begin{array}{l}-0.0149 \\
(0.0164)\end{array}$ & $\begin{array}{c}0.000455 \\
(0.0181)\end{array}$ \\
\hline Public School & & $\begin{array}{c}0.0421 * * * \\
(0.0120)\end{array}$ & $\begin{array}{c}0.0421 * * * \\
(0.0126)\end{array}$ & $\begin{array}{c}0.0428 * * * \\
(0.0124)\end{array}$ & $\begin{array}{c}0.0422 * * * \\
(0.0133)\end{array}$ \\
\hline Rural & & $\begin{array}{c}0.00966 \\
(0.00982)\end{array}$ & $\begin{array}{c}0.00966 \\
(0.00986)\end{array}$ & $\begin{array}{c}0.0115 \\
(0.00988)\end{array}$ & $\begin{array}{l}0.00404 \\
(0.0181)\end{array}$ \\
\hline Female & & $\begin{array}{l}0.0954 * * * \\
(0.00702)\end{array}$ & $\begin{array}{c}0.0954 * * * \\
(0.00848)\end{array}$ & $\begin{array}{c}0.0981 * * * \\
(0.00860)\end{array}$ & $\begin{array}{r}0.0952 * * * \\
(0.00954)\end{array}$ \\
\hline Married & & $\begin{array}{c}0.0185^{* * * *} \\
(0.00649)\end{array}$ & $\begin{array}{c}0.0185 * * * \\
(0.00692)\end{array}$ & $\begin{array}{c}0.0185 * * * \\
(0.00691)\end{array}$ & $\begin{array}{c}0.0148 * \\
(0.00761)\end{array}$ \\
\hline Chronic Illness & & $\begin{array}{c}0.00401 \\
(0.00641)\end{array}$ & $\begin{array}{c}0.00401 \\
(0.00657)\end{array}$ & $\begin{array}{l}0.000846 \\
(0.00683)\end{array}$ & $\begin{array}{l}-0.00438 \\
(0.00759)\end{array}$ \\
\hline Migrated & & $\begin{array}{c}0.0318 * * * \\
(0.00717)\end{array}$ & $\begin{array}{c}0.0318 * * * \\
(0.00742)\end{array}$ & $\begin{array}{c}0.0325 * * * \\
(0.00747)\end{array}$ & $\begin{array}{c}0.00615 \\
(0.00794)\end{array}$ \\
\hline & & - & - & - & - \\
\hline Tenure & & $\begin{array}{c}0.00149 * * * \\
(0.000275)\end{array}$ & $\begin{array}{c}0.00149 * * * \\
(0.000274)\end{array}$ & $\begin{array}{c}0.00175 * * * \\
(0.000304)\end{array}$ & $\begin{array}{c}0.00227 * * * \\
(0.000322)\end{array}$ \\
\hline Bedrooms & & $\begin{array}{c}-0.0104 * * * \\
(0.00209)\end{array}$ & $\begin{array}{c}-0.0104 * * * \\
(0.00208)\end{array}$ & $\begin{array}{c}-0.0109 * * * \\
(0.00208)\end{array}$ & $\begin{array}{c}-0.0118^{* * * *} \\
(0.00230)\end{array}$ \\
\hline Electricity & & $\begin{array}{c}0.000560 \\
(0.0101)\end{array}$ & $\begin{array}{l}0.000560 \\
(0.00994)\end{array}$ & $\begin{array}{c}-0.000365 \\
(0.0100)\end{array}$ & $\begin{array}{l}-0.00190 \\
(0.0131)\end{array}$ \\
\hline Piped Water & & $\begin{array}{l}-0.0157^{*} \\
(0.00867)\end{array}$ & $\begin{array}{l}-0.0157^{*} \\
(0.00933)\end{array}$ & $\begin{array}{l}-0.0160^{*} \\
(0.00939)\end{array}$ & $\begin{array}{l}-0.0185^{*} \\
(0.0111)\end{array}$ \\
\hline Landline & & $\begin{array}{c}-0.0217 * * \\
(0.0102)\end{array}$ & $\begin{array}{c}-0.0217 * * \\
(0.0100)\end{array}$ & $\begin{array}{c}-0.0255^{* *} \\
(0.0102)\end{array}$ & $\begin{array}{c}-0.0238^{* *} \\
(0.0112)\end{array}$ \\
\hline Mobile & & $\begin{array}{c}-0.0548 * * * \\
(0.00752)\end{array}$ & $\begin{array}{c}-0.0548 * * * \\
(0.00730)\end{array}$ & $\begin{array}{c}-0.0518 * * * \\
(0.00743)\end{array}$ & $\begin{array}{c}-0.0555^{* * * *} \\
(0.00863)\end{array}$ \\
\hline
\end{tabular}


Internet

Sanitation

Residents

Constant

$0.918 * * *$

$-0.0298 * *$

$-0.0298 * * *$

$-0.0269 * *$

$-0.0404 * * *$

$$
(0.0143)
$$

(0.0115)

(0.0115)

$(0.0125)$

$-0.00307$

$-0.00307$

$-0.00135$

$-0.0143$

$(0.00850)$

(0.00906)

$0.00632 * * *$

$0.00632 * *$

(0.00918)

(0.00917)

(0.00145)

$(0.00147)$

$0.00801 * * *$

$0.00832 * * *$

(0.00597)

(0.0201)

(0.0204)

(0.00143)

(0.00153)

$1.083^{* * *}$

$1.230 * * *$

(0.0259)

(0.101)

\section{Controls}

Basic

District Cluster

Age Fixed

District Fixed

\section{X}

$\mathbf{X}$
$\mathbf{X}$

$\mathbf{X}$
$\mathbf{X}$
$\mathbf{X}$

X

$\mathbf{X}$

$\mathrm{X}$

$\mathbf{X}$

Observations

14,423

0.405

12,611

12,611

12,611

12,611

R-squared

0.426

0.426

0.431

0.483

Note: $* * * \mathrm{p}<0.01,{ }^{* *} \mathrm{p}<0.05,{ }^{*} \mathrm{p}<0.1$. Robust standard errors in parentheses. Observations are for household heads. The dependent variable is a dummy variable indicating whether the individual falls into one of the following three categories: Salaried workers in small private firms, Unskilled self-employed and Zero income workers. See Table II for details on controls. 
Table IV Returns to education and productive informality for indigenous and non-indigenous workers, by language.

\begin{tabular}{|c|c|c|c|c|c|}
\hline $\begin{array}{l}\text { Legalistic } \\
\text { Informality } \\
(\text { No Pension }=1)\end{array}$ & (1) & $(2)$ & (3) & $(4)$ & (5) \\
\hline \multicolumn{6}{|l|}{ Indigenous } \\
\hline Language & $\begin{array}{c}0.0258 * * * \\
(0.00548) \\
-\end{array}$ & $\begin{array}{c}0.00788 \\
(0.00641)\end{array}$ & $\begin{array}{c}0.00788 \\
(0.00809)\end{array}$ & $\begin{array}{c}0.00912 \\
(0.00801)\end{array}$ & $\begin{array}{c}0.00872 \\
(0.00862)\end{array}$ \\
\hline Primary & $\begin{array}{r}0.0176 * * * \\
(0.00432)\end{array}$ & $\begin{array}{c}-0.0226 * * * \\
(0.00504)\end{array}$ & $\begin{array}{c}-0.0226 * * * \\
(0.00550)\end{array}$ & $\begin{array}{c}-0.0586^{* * *} \\
(0.00560)\end{array}$ & $\begin{array}{c}-0.0523 * * * \\
(0.00556)\end{array}$ \\
\hline Secondary & $\begin{array}{c}-0.175 * * * \\
(0.00563)\end{array}$ & $\begin{array}{c}-0.156^{* * * *} \\
(0.00672)\end{array}$ & $\begin{array}{c}-0.156^{* * * *} \\
(0.00829)\end{array}$ & $\begin{array}{c}-0.208^{* * * *} \\
(0.00857)\end{array}$ & $\begin{array}{c}-0.188^{* * * *} \\
(0.00853)\end{array}$ \\
\hline Tertiary & $\begin{array}{c}-0.544 * * * \\
(0.00759) \\
-\end{array}$ & $\begin{array}{l}-0.470 * * * \\
(0.00884)\end{array}$ & $\begin{array}{c}-0.470 * * * \\
(0.0109)\end{array}$ & $\begin{array}{c}-0.494 * * * \\
(0.0109)\end{array}$ & $\begin{array}{c}-0.473 * * * \\
(0.0115)\end{array}$ \\
\hline Language*Primary & $\begin{array}{r}0.0334 * * * \\
(0.00703)\end{array}$ & $\begin{array}{c}-0.0262 * * * \\
(0.00778)\end{array}$ & $\begin{array}{c}-0.0262 * * * \\
(0.00909)\end{array}$ & $\begin{array}{c}-0.0208^{* *} \\
(0.00880)\end{array}$ & $\begin{array}{c}-0.0271^{* * * *} \\
(0.00865)\end{array}$ \\
\hline \multicolumn{6}{|l|}{ Language*Secondar } \\
\hline $\mathrm{y}$ & $\begin{array}{c}0.0503 * * * \\
(0.0109)\end{array}$ & $\begin{array}{c}0.0535^{* * * *} \\
(0.0118)\end{array}$ & $\begin{array}{c}0.0535 * * * \\
(0.0147)\end{array}$ & $\begin{array}{c}0.0663 * * * \\
(0.0144)\end{array}$ & $\begin{array}{c}0.0433 * * * \\
(0.0140)\end{array}$ \\
\hline Language*Tertiary & $\begin{array}{l}0.00999 \\
(0.0219)\end{array}$ & $\begin{array}{l}0.0412^{*} \\
(0.0225)\end{array}$ & $\begin{array}{l}0.0412^{*} \\
(0.0237)\end{array}$ & $\begin{array}{c}0.0520 * * \\
(0.0237)\end{array}$ & $\begin{array}{c}0.0215 \\
(0.0256)\end{array}$ \\
\hline Public School & & $\begin{array}{c}-0.0216 * * * \\
(0.00701)\end{array}$ & $\begin{array}{c}-0.0216 * * * \\
(0.00755)\end{array}$ & $\begin{array}{l}-0.00348 \\
(0.00744)\end{array}$ & $\begin{array}{l}-0.00884 \\
(0.00721)\end{array}$ \\
\hline Rural & & $\begin{array}{c}0.0750 * * * \\
(0.00679)\end{array}$ & $\begin{array}{c}0.0750 * * * \\
(0.00897)\end{array}$ & $\begin{array}{c}0.0586 * * * \\
(0.00874)\end{array}$ & $\begin{array}{l}0.0198 * * \\
(0.00849)\end{array}$ \\
\hline Female & & $\begin{array}{l}0.136 * * * \\
(0.00392)\end{array}$ & $\begin{array}{l}0.136 * * * \\
(0.00579)\end{array}$ & $\begin{array}{l}0.136 * * * \\
(0.00574)\end{array}$ & $\begin{array}{l}0.135^{* * *} \\
(0.00583)\end{array}$ \\
\hline Married & & $\begin{array}{c}-0.0911 * * * \\
(0.00438)\end{array}$ & $\begin{array}{c}-0.0911 * * * \\
(0.00497)\end{array}$ & $\begin{array}{c}-0.0364 * * * \\
(0.00542)\end{array}$ & $\begin{array}{c}-0.0344 * * * \\
(0.00512)\end{array}$ \\
\hline Chronic Illness & & $\begin{array}{c}-0.0467 * * * \\
(0.00405)\end{array}$ & $\begin{array}{c}-0.0467 * * * \\
(0.00431)\end{array}$ & $\begin{array}{c}-0.0128 * * * \\
(0.00419)\end{array}$ & $\begin{array}{c}-0.0116^{* * * *} \\
(0.00391)\end{array}$ \\
\hline Migrated & & $\begin{array}{c}0.0412 * * * \\
(0.00450)\end{array}$ & $\begin{array}{c}0.0412 * * * \\
(0.00570)\end{array}$ & $\begin{array}{l}0.0221 * * * \\
(0.00587)\end{array}$ & $\begin{array}{l}0.00751 \\
(0.00493)\end{array}$ \\
\hline Tenure & & $\begin{array}{c}- \\
0.000719 * * * \\
(0.000187)\end{array}$ & $\begin{array}{c}- \\
0.000719 * * * \\
(0.000233)\end{array}$ & $\begin{array}{c}0.00206^{* *} \\
* \\
(0.000277)\end{array}$ & $\begin{array}{c}0.00190 * * \\
* \\
(0.000254)\end{array}$ \\
\hline Bedrooms & & $\begin{array}{l}-0.000362 \\
(0.00118)\end{array}$ & $\begin{array}{l}-0.000362 \\
(0.00121)\end{array}$ & $\begin{array}{l}-0.000125 \\
(0.00116)\end{array}$ & $\begin{array}{r}-0.000652 \\
(0.00118)\end{array}$ \\
\hline Electricity & & $\begin{array}{c}-0.0232 * * * \\
(0.00509)\end{array}$ & $\begin{array}{c}-0.0232 * * * \\
(0.00531)\end{array}$ & $\begin{array}{c}-0.0201 * * * \\
(0.00525)\end{array}$ & $\begin{array}{c}-0.0228 * * * \\
(0.00562)\end{array}$ \\
\hline Piped Water & & $\begin{array}{l}-0.0115^{* *} \\
(0.00533)\end{array}$ & $\begin{array}{l}-0.0115^{* *} \\
(0.00581)\end{array}$ & $\begin{array}{l}-0.00753 \\
(0.00577)\end{array}$ & $\begin{array}{c}-0.0144 * * \\
(0.00579)\end{array}$ \\
\hline Landline & & $-0.0624 * * *$ & $-0.0624 * * *$ & $-0.0495 * * *$ & $-0.0417 * * *$ \\
\hline
\end{tabular}


Mobile

Internet

Sanitation

Residents

Constant

$\begin{array}{cccc}(0.00672) & (0.00833) & (0.00826) & (0.00722) \\ -0.0363 * * * & -0.0363 * * * & -0.0406^{* * *} & -0.0370^{* * *} \\ (0.00427) & (0.00485) & (0.00485) & (0.00465) \\ -0.0674 * * * & -0.0674 * * * & -0.0742 * * * & -0.0577 * * * \\ (0.00951) & (0.0112) & (0.0111) & (0.0102) \\ -0.00442 & -0.00442 & -0.00658 & -0.00661 \\ (0.00506) & (0.00592) & (0.00594) & (0.00561) \\ & & 0.00420^{* *} & 0.00288^{* *} \\ 0.00827 * * * & 0.00827 * * * & * & * \\ (0.000781) & (0.000900) & (0.000863) & (0.000837) \\ 0.875 * * * & 0.875^{* * *} & 0.805 & 0.863 \\ (0.0118) & (0.0147) & & \end{array}$

\section{Controls}

$$
\begin{aligned}
& 0.912 * * * \\
& (0.00439)
\end{aligned}
$$

Basic

District Cluster

$\mathbf{X}$

Age Fixed

District Fixed

$$
\begin{aligned}
& \mathrm{X} \\
& \mathrm{X}
\end{aligned}
$$

Observations

62,993

0.181
44,728

0.282

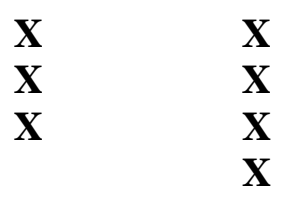

$44,728 \quad 44,728$

$0.306 \quad 0.354$

Note: $* * * \mathrm{p}<0.01, * * \mathrm{p}<0.05, * \mathrm{p}<0.1$. Robust standard errors in parentheses. Observations are for individuals over the age of 14 . See Table II for details on controls. 
Table V Heckman Selection Model specifications

\begin{tabular}{lcc}
\hline $\begin{array}{l}\text { Legalistic Informality } \\
\text { (No Pension = 1) }\end{array}$ & $\begin{array}{c}\text { Outcome Model } \\
(1)\end{array}$ & $\begin{array}{c}\text { Selection Model } \\
\text { Indigenous }\end{array}$ \\
Primary & $.0295714^{* *}$ & \\
Secondary & $-.0874244^{* * *}$ & \\
Tertiary & $-.328506^{* * *}$ & \\
I*Primary & $-.6496087^{* * *}$ & \\
I*Secondary & -.0021638 & \\
I*Tertiary & $.109773^{* * *}$ & \\
Rural & .0087755 & \\
Female & & -9.799894 \\
Married & & 1.81559 \\
Chronic Illness & & 7.733713 \\
Migrated & & -2.408933 \\
Bedrooms & & 5.302057 \\
Electricity & & -1.28784 \\
Piped Water & & 3.089751 \\
Landline & & -10.82551 \\
Mobile & & -10.94162 \\
Internet & & 3.557995 \\
Sanitation & & -.8561117 \\
Constant & & .3152604 \\
\end{tabular}

\section{Controls}

Age Fixed

District Fixed

$\mathrm{X}$

$\mathrm{X}$

Observations

14,758

Lambda

$-.1661514$

Rho

$-.42656$

Sigma 38951735

Note: $* * * \mathrm{p}<0.01, * * \mathrm{p}<0.05, * \mathrm{p}<0.1$. Robust standard errors in parenthesis. Model estimates a two-step Heckman selection model to identify the likelihood that individual is observed. See Table II for details on controls. 
Table VI Returns to education and pensionable employment by age cohort

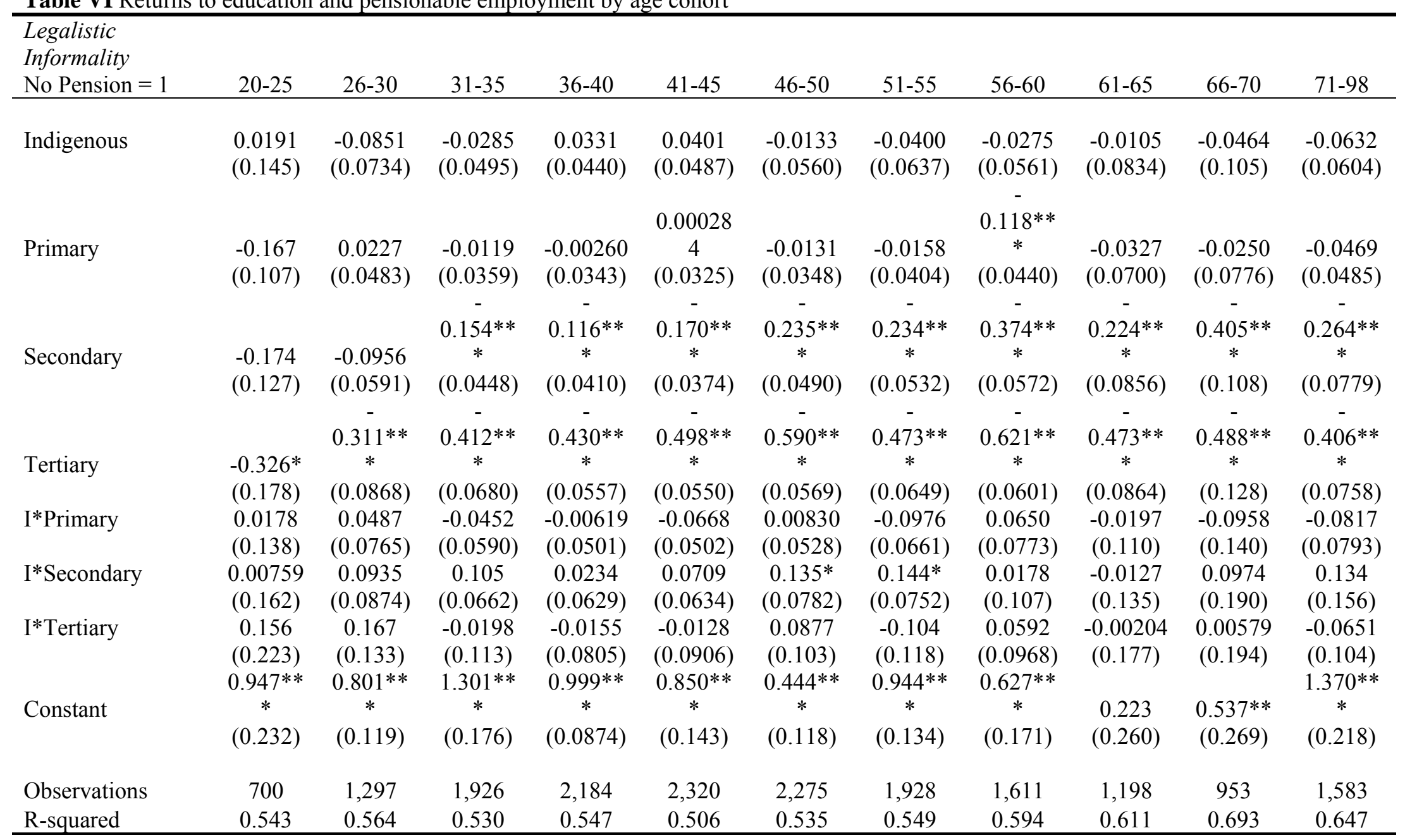

Note: $* * * \mathrm{p}<0.01, * * \mathrm{p}<0.05, * \mathrm{p}<0.1$. Robust standard errors in parentheses. Observations are household heads and spouses. Age Category $14-$ 19 was excluded due to limited observations. Results present most conservative specification from Table II. 
Table VII Returns to education by employment sector and status

\begin{tabular}{|c|c|c|c|c|c|c|c|}
\hline $\begin{array}{l}\text { Legalistic Informality } \\
\text { No Pension }=1\end{array}$ & $\frac{\text { Self-Employed }}{(1)}$ & $\begin{array}{c}\text { Salaried } \\
(2)\end{array}$ & $\begin{array}{c}\text { Microenterprise } \\
(3)\end{array}$ & $\begin{array}{l}\text { Public } \\
(4)\end{array}$ & $\frac{\text { Secondary Employment }}{(5)}$ & $\begin{array}{c}\text { Large Firm } \\
(6)\end{array}$ & $\frac{\text { Patron }}{(7)}$ \\
\hline Indigenous & $\begin{array}{l}0.00958 \\
(0.0158)\end{array}$ & $\begin{array}{l}0.0424 \\
(0.129)\end{array}$ & $\begin{array}{c}0.0117 \\
(0.0295)\end{array}$ & $\begin{array}{c}-0.359 * * \\
(0.144)\end{array}$ & $\begin{array}{l}-0.0172 \\
(0.0307)\end{array}$ & $\begin{array}{c}0.125 \\
(0.109)\end{array}$ & $\begin{array}{l}0.00696 \\
(0.0629)\end{array}$ \\
\hline Primary & $\begin{array}{c}-0.0650 * * * \\
(0.0114)\end{array}$ & $\begin{array}{l}-0.111^{*} \\
(0.0641)\end{array}$ & $\begin{array}{c}-0.0572 * * * \\
(0.0190)\end{array}$ & $\begin{array}{l}-0.241^{*} \\
(0.131)\end{array}$ & $\begin{array}{c}-0.0730 * * * \\
(0.0212)\end{array}$ & $\begin{array}{c}0.0217 \\
(0.0706)\end{array}$ & $\begin{array}{l}-0.0188 \\
(0.0417)\end{array}$ \\
\hline Secondary & $\begin{array}{c}-0.194 * * * \\
(0.0184)\end{array}$ & $\begin{array}{c}-0.385 * * * \\
(0.0574)\end{array}$ & $\begin{array}{c}-0.147 * * * \\
(0.0243)\end{array}$ & $\begin{array}{c}-0.368 * * * \\
(0.115)\end{array}$ & $\begin{array}{c}-0.277 * * * \\
(0.0313)\end{array}$ & $\begin{array}{l}-0.152^{* *} \\
(0.0760)\end{array}$ & $\begin{array}{c}-0.173^{* * *} \\
(0.0587)\end{array}$ \\
\hline Tertiary & $\begin{array}{c}-0.379 * * * \\
(0.0305)\end{array}$ & $\begin{array}{c}-0.534 * * * \\
(0.0553)\end{array}$ & $\begin{array}{l}-0.403 * * * \\
(0.0425)\end{array}$ & $\begin{array}{l}-0.464 * * * \\
(0.111)\end{array}$ & $\begin{array}{c}-0.602 * * * \\
(0.0362)\end{array}$ & $\begin{array}{l}-0.188^{* *} \\
(0.0843)\end{array}$ & $\begin{array}{c}-0.444 * * * \\
(0.0722)\end{array}$ \\
\hline I*Primary & $\begin{array}{l}-0.0286^{*} \\
(0.0172)\end{array}$ & $\begin{array}{c}-0.00729 \\
(0.140)\end{array}$ & $\begin{array}{l}-0.0180 \\
(0.0349)\end{array}$ & $\begin{array}{l}0.354 * * \\
(0.167)\end{array}$ & $\begin{array}{c}0.0112 \\
(0.0328)\end{array}$ & $\begin{array}{l}-0.187 \\
(0.120)\end{array}$ & $\begin{array}{l}-0.0636 \\
(0.0678)\end{array}$ \\
\hline$I^{*}$ Secondary & $\begin{array}{l}0.0519^{*} \\
(0.0268)\end{array}$ & $\begin{array}{l}-0.0378 \\
(0.131)\end{array}$ & $\begin{array}{c}0.0218 \\
(0.0426)\end{array}$ & $\begin{array}{l}0.315^{* *} \\
(0.154)\end{array}$ & $\begin{array}{c}0.0525 \\
(0.0429)\end{array}$ & $\begin{array}{l}-0.0196 \\
(0.128)\end{array}$ & $\begin{array}{c}0.0449 \\
(0.0925)\end{array}$ \\
\hline I*Tertiary & $\begin{array}{l}-0.0148 \\
(0.0565)\end{array}$ & $\begin{array}{l}-0.0587 \\
(0.123)\end{array}$ & $\begin{array}{c}0.109 \\
(0.0836)\end{array}$ & $\begin{array}{l}0.314^{* *} \\
(0.148)\end{array}$ & $\begin{array}{c}0.0516 \\
(0.0635)\end{array}$ & $\begin{array}{l}-0.149 \\
(0.130)\end{array}$ & $\begin{array}{c}0.226 \\
(0.137)\end{array}$ \\
\hline Rural & $\begin{array}{l}-0.0371 \\
(0.0233)\end{array}$ & $\begin{array}{c}0.0267 \\
(0.0266)\end{array}$ & $\begin{array}{l}-0.0489 \\
(0.0325)\end{array}$ & $\begin{array}{l}-0.0278 \\
(0.0271)\end{array}$ & $\begin{array}{l}-0.0364 \\
(0.0327)\end{array}$ & $\begin{array}{l}0.00305 \\
(0.0352)\end{array}$ & $\begin{array}{l}0.00598 \\
(0.0612)\end{array}$ \\
\hline Female & $\begin{array}{c}-0.0374 * * \\
(0.0184)\end{array}$ & $\begin{array}{c}0.0159 \\
(0.0978)\end{array}$ & $\begin{array}{r}-0.00488 \\
(0.0347)\end{array}$ & $\begin{array}{l}-0.0405 \\
(0.0817)\end{array}$ & $\begin{array}{c}0.0403 \\
(0.0313)\end{array}$ & $\begin{array}{l}0.143 * * \\
(0.0722)\end{array}$ & $\begin{array}{c}0.0260 \\
(0.0580)\end{array}$ \\
\hline Married & $\begin{array}{l}-0.0206 * * \\
(0.00936)\end{array}$ & $\begin{array}{c}-0.0543 * * * \\
(0.0204)\end{array}$ & $\begin{array}{l}-0.0213 \\
(0.0175)\end{array}$ & $\begin{array}{l}-0.0149 \\
(0.0223)\end{array}$ & $\begin{array}{c}-0.0448 * * \\
(0.0179)\end{array}$ & $\begin{array}{l}-0.0514 \\
(0.0321)\end{array}$ & $\begin{array}{c}-0.0861 * * \\
(0.0347)\end{array}$ \\
\hline Chronic Illness & $\begin{array}{l}-0.00332 \\
(0.00886)\end{array}$ & $\begin{array}{c}0.000552 \\
(0.0199)\end{array}$ & $\begin{array}{c}0.0155 \\
(0.0187)\end{array}$ & $\begin{array}{c}0.0159 \\
(0.0206)\end{array}$ & $\begin{array}{c}0.0148 \\
(0.0169)\end{array}$ & $\begin{array}{l}0.00153 \\
(0.0299)\end{array}$ & $\begin{array}{l}0.00127 \\
(0.0357)\end{array}$ \\
\hline Migrated & $\begin{array}{l}0.00970 \\
(0.0112)\end{array}$ & $\begin{array}{c}0.0327 \\
(0.0248)\end{array}$ & $\begin{array}{l}-0.0131 \\
(0.0182)\end{array}$ & $\begin{array}{c}0.0477 * * \\
(0.0241)\end{array}$ & $\begin{array}{l}-0.00444 \\
(0.0179)\end{array}$ & $\begin{array}{l}0.00501 \\
(0.0342)\end{array}$ & $\begin{array}{l}0.00838 \\
(0.0389)\end{array}$ \\
\hline Tenure & $\begin{array}{c}0.00299 * * * \\
(0.000395)\end{array}$ & $\begin{array}{c}-0.00893^{* * *} \\
(0.00134)\end{array}$ & $\begin{array}{c}0.00263 * * * \\
(0.000791)\end{array}$ & $\begin{array}{c}-0.00627 * * * \\
(0.00123)\end{array}$ & $\begin{array}{l}-0.00183 * * \\
(0.000773)\end{array}$ & $\begin{array}{c}-0.00651 * * * \\
(0.00200)\end{array}$ & $\begin{array}{c}0.00490 * * * \\
(0.00166)\end{array}$ \\
\hline Bedrooms & $\begin{array}{c}-0.00616^{* *} \\
(0.00297)\end{array}$ & $\begin{array}{l}-0.0117 * * \\
(0.00578)\end{array}$ & $\begin{array}{l}-0.0101^{*} \\
(0.00535)\end{array}$ & $\begin{array}{l}-0.00524 \\
(0.00553)\end{array}$ & $\begin{array}{c}0.00245 \\
(0.00479)\end{array}$ & $\begin{array}{l}-0.00776 \\
(0.00962)\end{array}$ & $\begin{array}{l}-0.00779 \\
(0.00968)\end{array}$ \\
\hline Electricity & $\begin{array}{l}-0.00403 \\
(0.0116)\end{array}$ & $\begin{array}{l}-0.0923 \\
(0.0794)\end{array}$ & $\begin{array}{l}0.00135 \\
(0.0235)\end{array}$ & $\begin{array}{l}-0.00215 \\
(0.0904)\end{array}$ & $\begin{array}{c}-0.0637 * * \\
(0.0252)\end{array}$ & $\begin{array}{c}-0.207^{* * *} \\
(0.0623)\end{array}$ & $\begin{array}{c}0.0567 \\
(0.0471)\end{array}$ \\
\hline Piped Water & $\begin{array}{r}-0.00467 \\
(0.0126)\end{array}$ & $\begin{array}{l}-0.0258 \\
(0.0398)\end{array}$ & $\begin{array}{c}-0.0496^{* *} \\
(0.0206)\end{array}$ & $\begin{array}{c}0.0165 \\
(0.0578)\end{array}$ & $\begin{array}{l}-0.00300 \\
(0.0264)\end{array}$ & $\begin{array}{c}0.0494 \\
(0.0437)\end{array}$ & $\begin{array}{l}-0.0442 \\
(0.0479)\end{array}$ \\
\hline
\end{tabular}




\begin{tabular}{|c|c|c|c|c|c|c|c|}
\hline Landline & $\begin{array}{c}-0.0455 * * * \\
(0.0173)\end{array}$ & $\begin{array}{l}-0.0290 \\
(0.0243)\end{array}$ & $\begin{array}{l}-0.0453 \\
(0.0304)\end{array}$ & $\begin{array}{l}0.00310 \\
(0.0221)\end{array}$ & $\begin{array}{l}-0.0286 \\
(0.0289)\end{array}$ & $\begin{array}{c}-0.0673 * \\
(0.0382)\end{array}$ & $\begin{array}{l}-0.0303 \\
(0.0490)\end{array}$ \\
\hline \multirow[t]{2}{*}{ Mobile } & $-0.0284 * * *$ & -0.0397 & -0.0252 & -0.0239 & $-0.0462 * *$ & -0.0512 & -0.00865 \\
\hline & $(0.00966)$ & $(0.0367)$ & $(0.0190)$ & $(0.0438)$ & $(0.0199)$ & $(0.0486)$ & $(0.0398)$ \\
\hline \multirow[t]{2}{*}{ Internet } & -0.0367 & $-0.0485 * *$ & 0.0143 & -0.0222 & $-0.114 * * *$ & -0.0328 & 0.0374 \\
\hline & $(0.0316)$ & $(0.0234)$ & $(0.0422)$ & $(0.0230)$ & $(0.0431)$ & $(0.0436)$ & $(0.0642)$ \\
\hline \multirow[t]{2}{*}{ Sanitation } & -0.0156 & -0.0569 & -0.0115 & -0.0710 & 0.0114 & -0.00532 & 0.0148 \\
\hline & $(0.0113)$ & $(0.0427)$ & $(0.0220)$ & $(0.0538)$ & $(0.0204)$ & $(0.0489)$ & $(0.0483)$ \\
\hline \multirow[t]{2}{*}{ Residents } & 0.00285 & $0.0106^{* *}$ & 0.000807 & $0.0130 * *$ & 0.00412 & 0.00400 & -0.00473 \\
\hline & $(0.00190)$ & $(0.00491)$ & $(0.00375)$ & $(0.00627)$ & $(0.00314)$ & $(0.00715)$ & $(0.00710)$ \\
\hline \multirow[t]{2}{*}{ Constant } & 0.0672 & $1.693 * * *$ & $0.954 * * *$ & $1.436 * * *$ & $1.070 * * *$ & $2.444 * * *$ & -0.314 \\
\hline & $(0.124)$ & $(0.231)$ & $(0.178)$ & $(0.152)$ & $(0.0640)$ & $(0.290)$ & $(0.262)$ \\
\hline Observations & 8,032 & 2,066 & 3,616 & 1,509 & 3,891 & 1,647 & 1,494 \\
\hline $\mathrm{R}$-squared & 0.317 & 0.524 & 0.398 & 0.582 & 0.496 & 0.494 & 0.545 \\
\hline
\end{tabular}


Table VIII Triple Interaction effects of Self-Employment on educational outcomes

\begin{tabular}{|c|c|c|c|c|c|}
\hline $\begin{array}{l}\text { Legalistic } \\
\text { Informality } \\
(\text { No Pension = 1) } \\
\end{array}$ & (1) & $(2)$ & (3) & (4) & $(5)$ \\
\hline Indigenous & $\begin{array}{c}0.0169 \\
(0.0136)\end{array}$ & $\begin{array}{c}0.00848 \\
(0.0161)\end{array}$ & $\begin{array}{c}0.00848 \\
(0.0174)\end{array}$ & $\begin{array}{c}0.00726 \\
(0.0175)\end{array}$ & $\begin{array}{c}0.0149 \\
(0.0192)\end{array}$ \\
\hline Primary & $\begin{array}{c}-0.135^{* * *} \\
(0.0152)\end{array}$ & $\begin{array}{c}-0.0442 * * * \\
(0.0153)\end{array}$ & $\begin{array}{c}-0.0442 * * * \\
(0.0151)\end{array}$ & $\begin{array}{c}-0.0694 * * * \\
(0.0154)\end{array}$ & $\begin{array}{c}-0.0530 * * * \\
(0.0158)\end{array}$ \\
\hline Secondary & $\begin{array}{c}-0.422 * * * \\
(0.0156)\end{array}$ & $\begin{array}{c}-0.250 * * * \\
(0.0179)\end{array}$ & $\begin{array}{c}-0.250 * * * \\
(0.0186)\end{array}$ & $\begin{array}{c}-0.297 * * * \\
(0.0188)\end{array}$ & $\begin{array}{c}-0.262 * * * \\
(0.0190)\end{array}$ \\
\hline Tertiary & $\begin{array}{c}-0.714 * * * \\
(0.0144)\end{array}$ & $\begin{array}{c}-0.516^{* * *} \\
(0.0183)\end{array}$ & $\begin{array}{c}-0.516^{* * *} \\
(0.0214)\end{array}$ & $\begin{array}{c}-0.568 * * * \\
(0.0216)\end{array}$ & $\begin{array}{c}-0.542 * * * \\
(0.0230)\end{array}$ \\
\hline Self Employed & $\begin{array}{c}0.0434 * * * \\
(0.0115)\end{array}$ & $\begin{array}{c}0.0845^{* * *} * \\
(0.0132)\end{array}$ & $\begin{array}{c}0.0845^{* * *} * \\
(0.0129)\end{array}$ & $\begin{array}{c}0.0846^{* * *} \\
(0.0132)\end{array}$ & $\begin{array}{c}0.0841 * * * \\
(0.0132)\end{array}$ \\
\hline I*Primary & $\begin{array}{c}-0.00902 \\
(0.0238)\end{array}$ & $\begin{array}{l}-0.00504 \\
(0.0237)\end{array}$ & $\begin{array}{r}-0.00504 \\
(0.0233)\end{array}$ & $\begin{array}{c}-0.00852 \\
(0.0234)\end{array}$ & $\begin{array}{l}-0.0216 \\
(0.0243)\end{array}$ \\
\hline I*Secondary & $\begin{array}{c}0.121^{* * *} \\
(0.0269)\end{array}$ & $\begin{array}{c}0.0963 * * * \\
(0.0276)\end{array}$ & $\begin{array}{c}0.0963 * * * \\
(0.0294)\end{array}$ & $\begin{array}{c}0.0912 * * * \\
(0.0290)\end{array}$ & $\begin{array}{c}0.0632 * * \\
(0.0288)\end{array}$ \\
\hline $\mathrm{I}^{*}$ Tertiary & $\begin{array}{c}0.0352 \\
(0.0280)\end{array}$ & $\begin{array}{c}0.0122 \\
(0.0297)\end{array}$ & $\begin{array}{c}0.0122 \\
(0.0304)\end{array}$ & $\begin{array}{c}0.0136 \\
(0.0299)\end{array}$ & $\begin{array}{l}-0.0100 \\
(0.0320)\end{array}$ \\
\hline I*Self Employed & $\begin{array}{c}0.000925 \\
(0.0158)\end{array}$ & $\begin{array}{r}-0.00573 \\
(0.0186)\end{array}$ & $\begin{array}{r}-0.00573 \\
(0.0182)\end{array}$ & $\begin{array}{l}-0.0106 \\
(0.0181)\end{array}$ & $\begin{array}{l}-0.0121 \\
(0.0181)\end{array}$ \\
\hline Self*Primary & $\begin{array}{c}0.0781 * * * \\
(0.0181)\end{array}$ & $\begin{array}{c}0.0282 \\
(0.0183)\end{array}$ & $\begin{array}{l}0.0282^{*} \\
(0.0169)\end{array}$ & $\begin{array}{l}0.0314^{*} \\
(0.0171)\end{array}$ & $\begin{array}{c}0.0232 \\
(0.0168)\end{array}$ \\
\hline Self*Secondary & $\begin{array}{c}0.210 * * * \\
(0.0211)\end{array}$ & $\begin{array}{c}0.137 * * * \\
(0.0217)\end{array}$ & $\begin{array}{c}0.137 * * * \\
(0.0213)\end{array}$ & $\begin{array}{c}0.143 * * * \\
(0.0214)\end{array}$ & $\begin{array}{c}0.128 * * * \\
(0.0211)\end{array}$ \\
\hline Self*Tertiary & $\begin{array}{c}0.270^{* * *} \\
(0.0285)\end{array}$ & $\begin{array}{c}0.212 * * * \\
(0.0290)\end{array}$ & $\begin{array}{c}0.212 * * * \\
(0.0295)\end{array}$ & $\begin{array}{c}0.234 * * * \\
(0.0290)\end{array}$ & $\begin{array}{c}0.237 * * * \\
(0.0302)\end{array}$ \\
\hline I*Self*Primary & $\begin{array}{r}-0.00525 \\
(0.0278)\end{array}$ & $\begin{array}{r}-0.00839 \\
(0.0278)\end{array}$ & $\begin{array}{r}-0.00839 \\
(0.0274)\end{array}$ & $\begin{array}{l}-0.0104 \\
(0.0275)\end{array}$ & $\begin{array}{c}0.000690 \\
(0.0274)\end{array}$ \\
\hline I*Self*Secondary & $\begin{array}{l}-0.0326 \\
(0.0349)\end{array}$ & $\begin{array}{l}-0.0238 \\
(0.0361)\end{array}$ & $\begin{array}{c}-0.0238 \\
(0.0349)\end{array}$ & $\begin{array}{l}-0.0197 \\
(0.0350)\end{array}$ & $\begin{array}{c}-0.00609 \\
(0.0345)\end{array}$ \\
\hline I*Self*Tertiary & $\begin{array}{c}0.0341 \\
(0.0565)\end{array}$ & $\begin{array}{c}0.0254 \\
(0.0563)\end{array}$ & $\begin{array}{c}0.0254 \\
(0.0541)\end{array}$ & $\begin{array}{c}0.0228 \\
(0.0528)\end{array}$ & $\begin{array}{c}0.0164 \\
(0.0577)\end{array}$ \\
\hline Public School & & $\begin{array}{c}-0.0289^{* *} \\
(0.0134)\end{array}$ & $\begin{array}{c}-0.0289 * * \\
(0.0124)\end{array}$ & $\begin{array}{l}-0.0182 \\
(0.0125)\end{array}$ & $\begin{array}{l}-0.0217^{*} \\
(0.0131)\end{array}$ \\
\hline Rural & & $\begin{array}{c}0.0886^{* * * *} \\
(0.0105)\end{array}$ & $\begin{array}{c}0.0886^{* * * *} \\
(0.0129)\end{array}$ & $\begin{array}{c}0.0789 * * * \\
(0.0126)\end{array}$ & $\begin{array}{c}0.0333 * * \\
(0.0142)\end{array}$ \\
\hline Female & & $\begin{array}{c}0.195 * * * \\
(0.00712)\end{array}$ & $\begin{array}{c}0.195 * * * \\
(0.00904)\end{array}$ & $\begin{array}{c}0.187 * * * \\
(0.00899)\end{array}$ & $\begin{array}{l}0.199 * * * \\
(0.00937)\end{array}$ \\
\hline Married & & $\begin{array}{c}-0.0264 * * * \\
(0.00647)\end{array}$ & $\begin{array}{c}-0.0264 * * * \\
(0.00643)\end{array}$ & $\begin{array}{c}-0.0129 * * \\
(0.00653)\end{array}$ & $\begin{array}{l}-0.00581 \\
(0.00650)\end{array}$ \\
\hline Chronic Illness & & $\begin{array}{c}-0.0413 * * * \\
(0.00627)\end{array}$ & $\begin{array}{c}-0.0413 * * * \\
(0.00644)\end{array}$ & $\begin{array}{c}-0.0143 * * \\
(0.00661)\end{array}$ & $\begin{array}{c}-0.0155^{* *} \\
(0.00687)\end{array}$ \\
\hline Migrated & & $0.0189 * * *$ & $0.0189 * *$ & 0.0133 & 0.00315 \\
\hline
\end{tabular}




\begin{tabular}{|c|c|c|c|c|c|}
\hline & & $(0.00721)$ & $(0.00825)$ & $(0.00828)$ & $(0.00804)$ \\
\hline \multirow[t]{2}{*}{ Tenure } & & 0.000409 & 0.000409 & $0.00237 * * *$ & $0.00216^{* * *}$ \\
\hline & & $(0.000270)$ & $(0.000313)$ & $(0.000364)$ & $(0.000325)$ \\
\hline \multirow[t]{2}{*}{ Bedrooms } & & $-0.0105 * * *$ & $-0.0105 * * *$ & $-0.00492 * *$ & $-0.00752 * * *$ \\
\hline & & (0.00199) & $(0.00207)$ & $(0.00203)$ & (0.00209) \\
\hline \multirow[t]{2}{*}{ Electric } & & $-0.0579 * * *$ & $-0.0579 * * *$ & $-0.0520 * * *$ & $-0.0393 * * *$ \\
\hline & & $(0.00863)$ & $(0.00873)$ & $(0.00858)$ & $(0.00926)$ \\
\hline \multirow[t]{2}{*}{ Piped Water } & & $-0.0140 *$ & -0.0140 & -0.00783 & $-0.0188 *$ \\
\hline & & $(0.00844)$ & $(0.00901)$ & $(0.00894)$ & $(0.00969)$ \\
\hline \multirow[t]{2}{*}{ Landline } & & $-0.0835 * * *$ & $-0.0835 * * *$ & $-0.0623 * * *$ & $-0.0596 * * *$ \\
\hline & & $(0.0111)$ & $(0.0127)$ & $(0.0126)$ & $(0.0126)$ \\
\hline \multirow[t]{2}{*}{ Mobile } & & $-0.0409 * * *$ & $-0.0409 * * *$ & $-0.0478 * * *$ & $-0.0332 * * *$ \\
\hline & & $(0.00719)$ & $(0.00807)$ & $(0.00796)$ & $(0.00796)$ \\
\hline \multirow[t]{2}{*}{ Internet } & & $-0.0372 * *$ & $-0.0372 * *$ & $-0.0435 * *$ & -0.0270 \\
\hline & & $(0.0149)$ & $(0.0179)$ & $(0.0180)$ & $(0.0175)$ \\
\hline \multirow[t]{2}{*}{ Sanitation } & & $-0.0140 *$ & -0.0140 & $-0.0153^{*}$ & $-0.0173^{*}$ \\
\hline & & $(0.00804)$ & (0.00919) & $(0.00917)$ & $(0.00931)$ \\
\hline \multirow[t]{2}{*}{ Residents } & & $0.00753 * * *$ & $0.00753 * * *$ & $0.00480 * * *$ & 0.00155 \\
\hline & & $(0.00134)$ & $(0.00144)$ & $(0.00148)$ & $(0.00150)$ \\
\hline \multirow[t]{2}{*}{ Constant } & $0.886^{* * *}$ & $0.823 * * *$ & $0.823 * * *$ & $1.198 * * *$ & $1.017 * * *$ \\
\hline & $(0.00971)$ & $(0.0226)$ & $(0.0260)$ & $(0.0378)$ & $(0.198)$ \\
\hline
\end{tabular}

Controls

Basic

District Cluster

X

$\begin{array}{ccccc} & \mathbf{X} & \mathbf{X} & \mathbf{X} & \mathbf{X} \\ & & \mathbf{X} & \mathbf{X} & \mathbf{X} \\ & & & \mathbf{X} & \mathbf{X} \\ & & & & \mathbf{X} \\ 17,352 & 15,309 & 15,309 & 15,309 & 15,309 \\ 0.276 & 0.340 & 0.340 & 0.356 & 0.436\end{array}$

District Fixed

Observations

0.276

0.340

0.340

0.356

0.436

Note: $* * * \mathrm{p}<0.01, * * \mathrm{p}<0.05, * \mathrm{p}<0.1$. Robust standard errors in parentheses. See Table II for details on controls 
Table IX Triple Interaction effects of Migration on employment outcomes

\begin{tabular}{|c|c|c|c|c|c|}
\hline $\begin{array}{l}\text { Legalistic Informality } \\
(\text { No Pension }=1)\end{array}$ & $(1)$ & (2) & (3) & (4) & $(5)$ \\
\hline Indigenous & $\begin{array}{c}-0.0482 * * * \\
(0.0131)\end{array}$ & $\begin{array}{l}-0.0199 \\
(0.0160)\end{array}$ & $\begin{array}{l}-0.0199 \\
(0.0183)\end{array}$ & $\begin{array}{l}-0.0260 \\
(0.0181)\end{array}$ & $\begin{array}{c}0.000372 \\
(0.0189)\end{array}$ \\
\hline Primary & $\begin{array}{l}-0.113 * * * \\
(0.0108)\end{array}$ & $\begin{array}{c}-0.0367 * * * \\
(0.0128)\end{array}$ & $\begin{array}{c}-0.0367 * * * \\
(0.0135)\end{array}$ & $\begin{array}{c}-0.0571 * * * \\
(0.0135)\end{array}$ & $\begin{array}{c}-0.0422 * * * \\
(0.0139)\end{array}$ \\
\hline Secondary & $\begin{array}{c}-0.323 * * * \\
(0.0124)\end{array}$ & $\begin{array}{c}-0.214 * * * \\
(0.0156)\end{array}$ & $\begin{array}{c}-0.214 * * * \\
(0.0175)\end{array}$ & $\begin{array}{c}-0.256^{* * *} \\
(0.0175)\end{array}$ & $\begin{array}{c}-0.216 * * * \\
(0.0177)\end{array}$ \\
\hline Tertiary & $\begin{array}{c}-0.620 * * * \\
(0.0137)\end{array}$ & $\begin{array}{c}-0.477 * * * \\
(0.0183)\end{array}$ & $\begin{array}{c}-0.477 * * * \\
(0.0214)\end{array}$ & $\begin{array}{c}-0.520 * * * \\
(0.0215)\end{array}$ & $\begin{array}{c}-0.483 * * * \\
(0.0232)\end{array}$ \\
\hline I*Primary & $\begin{array}{c}0.0291 \\
(0.0209)\end{array}$ & $\begin{array}{l}-0.0108 \\
(0.0225)\end{array}$ & $\begin{array}{l}-0.0108 \\
(0.0227)\end{array}$ & $\begin{array}{l}-0.0108 \\
(0.0226)\end{array}$ & $\begin{array}{l}-0.0275 \\
(0.0232)\end{array}$ \\
\hline$I^{*}$ Secondary & $\begin{array}{l}0.160 * * * \\
(0.0230)\end{array}$ & $\begin{array}{l}0.116 * * * \\
(0.0253)\end{array}$ & $\begin{array}{l}0.116 * * * \\
(0.0277)\end{array}$ & $\begin{array}{l}0.117 * * * \\
(0.0275)\end{array}$ & $\begin{array}{c}0.0753 * * * \\
(0.0280)\end{array}$ \\
\hline I*Tertiary & $\begin{array}{l}0.0784 * * \\
(0.0305)\end{array}$ & $\begin{array}{c}0.0188 \\
(0.0341)\end{array}$ & $\begin{array}{c}0.0188 \\
(0.0397)\end{array}$ & $\begin{array}{c}0.0231 \\
(0.0386)\end{array}$ & $\begin{array}{l}-0.0255 \\
(0.0403)\end{array}$ \\
\hline I*Migrated & $\begin{array}{l}0.123 * * * \\
(0.0126)\end{array}$ & $\begin{array}{c}0.0530 * * * \\
(0.0195)\end{array}$ & $\begin{array}{l}0.0530 * * \\
(0.0212)\end{array}$ & $\begin{array}{c}0.0564 * * * \\
(0.0210)\end{array}$ & $\begin{array}{c}0.0252 \\
(0.0221)\end{array}$ \\
\hline Migrated*Primary & $\begin{array}{c}0.0734 * * * \\
(0.0131)\end{array}$ & $\begin{array}{c}0.0259 \\
(0.0173)\end{array}$ & $\begin{array}{c}0.0259 \\
(0.0179)\end{array}$ & $\begin{array}{c}0.0252 \\
(0.0176)\end{array}$ & $\begin{array}{c}0.0236 \\
(0.0174)\end{array}$ \\
\hline Migrated*Secondary & $\begin{array}{c}0.0675 * * * \\
(0.0167)\end{array}$ & $\begin{array}{l}0.0436 * * \\
(0.0213)\end{array}$ & $\begin{array}{l}0.0436^{* *} \\
(0.0221)\end{array}$ & $\begin{array}{l}0.0473 * * \\
(0.0218)\end{array}$ & $\begin{array}{c}0.0291 \\
(0.0230)\end{array}$ \\
\hline Migrated*Tertiary & $\begin{array}{l}0.00200 \\
(0.0211)\end{array}$ & $\begin{array}{l}-0.0137 \\
(0.0258)\end{array}$ & $\begin{array}{l}-0.0137 \\
(0.0271)\end{array}$ & $\begin{array}{l}-0.0110 \\
(0.0273)\end{array}$ & $\begin{array}{l}-0.0271 \\
(0.0298)\end{array}$ \\
\hline I*Migrated*Primary & $\begin{array}{c}-0.0638^{* *} \\
(0.0249)\end{array}$ & $\begin{array}{l}-0.00116 \\
(0.0284)\end{array}$ & $\begin{array}{l}-0.00116 \\
(0.0292)\end{array}$ & $\begin{array}{l}-0.00805 \\
(0.0289)\end{array}$ & $\begin{array}{l}0.00346 \\
(0.0289)\end{array}$ \\
\hline I*Migrated*Secondary & $\begin{array}{c}-0.111 * * * \\
(0.0323)\end{array}$ & $\begin{array}{l}-0.0510 \\
(0.0360)\end{array}$ & $\begin{array}{l}-0.0510 \\
(0.0349)\end{array}$ & $\begin{array}{l}-0.0541 \\
(0.0347)\end{array}$ & $\begin{array}{l}-0.0251 \\
(0.0365)\end{array}$ \\
\hline I*Migrated*Tertiary & $\begin{array}{l}-0.0474 \\
(0.0496)\end{array}$ & $\begin{array}{c}0.0365 \\
(0.0536)\end{array}$ & $\begin{array}{c}0.0365 \\
(0.0590)\end{array}$ & $\begin{array}{c}0.0336 \\
(0.0588)\end{array}$ & $\begin{array}{c}0.0761 \\
(0.0631)\end{array}$ \\
\hline Public School & & $\begin{array}{c}-0.0302^{* *} \\
(0.0138)\end{array}$ & $\begin{array}{c}-0.0302 * * \\
(0.0127)\end{array}$ & $\begin{array}{l}-0.0204 \\
(0.0127)\end{array}$ & $\begin{array}{l}-0.0245^{*} \\
(0.0132)\end{array}$ \\
\hline Rural & & $\begin{array}{c}0.0876^{* * * *} \\
(0.0107)\end{array}$ & $\begin{array}{c}0.0876 * * * \\
(0.0130)\end{array}$ & $\begin{array}{c}0.0790 * * * \\
(0.0127)\end{array}$ & $\begin{array}{c}0.0367 * * * \\
(0.0142)\end{array}$ \\
\hline Female & & $\begin{array}{l}0.202 * * * \\
(0.00730)\end{array}$ & $\begin{array}{l}0.202 * * * \\
(0.00939)\end{array}$ & $\begin{array}{l}0.195 * * * \\
(0.00933)\end{array}$ & $\begin{array}{l}0.207 * * * \\
(0.00971)\end{array}$ \\
\hline Married & & $\begin{array}{c}-0.0300 * * * \\
(0.00668)\end{array}$ & $\begin{array}{c}-0.0300 * * * \\
(0.00676)\end{array}$ & $\begin{array}{r}-0.0175^{* *} \\
(0.00688)\end{array}$ & $\begin{array}{l}-0.00948 \\
(0.00693)\end{array}$ \\
\hline Chronic Illness & & $\begin{array}{c}-0.0368 * * * \\
(0.00638)\end{array}$ & $\begin{array}{c}-0.0368 * * * \\
(0.00648)\end{array}$ & $\begin{array}{l}-0.0118^{*} \\
(0.00671)\end{array}$ & $\begin{array}{l}-0.0145^{* *} \\
(0.00702)\end{array}$ \\
\hline Migrated & & $\begin{array}{l}-0.00949 \\
(0.0128)\end{array}$ & $\begin{array}{l}-0.00949 \\
(0.0142)\end{array}$ & $\begin{array}{l}-0.0159 \\
(0.0140)\end{array}$ & $\begin{array}{l}-0.0159 \\
(0.0143)\end{array}$ \\
\hline Tenure & & $\begin{array}{c}0.00102 * * * \\
(0.000269)\end{array}$ & $\begin{array}{c}0.00102 * * * \\
(0.000309)\end{array}$ & $\begin{array}{c}0.00281 * * * \\
(0.000355)\end{array}$ & $\begin{array}{c}0.00253 * * * \\
(0.000320)\end{array}$ \\
\hline
\end{tabular}


Bedrooms

Electricity

Piped Water

Landline

Mobile

Internet

Sanitation

Residents

Constant

Controls

Basic

District Cluster

Age Fixed

District Fixed

Observations

R-squared

20,534

0.216

$\begin{array}{cccc}-0.0109 * * * & -0.0109 * * * & -0.00580 * * * & -0.00840 * * * \\ (0.00204) & (0.00208) & (0.00205) & (0.00211) \\ -0.0586 * * * & -0.0586^{* * *} & -0.0533 * * * & -0.0381 * * * \\ (0.00868) & (0.00877) & (0.00862) & (0.00941) \\ -0.0171 * * & -0.0171 * & -0.0115 & -0.0235 * * \\ (0.00864) & (0.00907) & (0.00902) & (0.00980) \\ -0.0822^{* * *} & -0.0822^{* * *} & -0.0626^{* * *} & -0.0588^{* * *} \\ (0.0114) & (0.0131) & (0.0130) & (0.0128) \\ -0.0502^{* * *} & -0.0502 * * * & -0.0568 * * * & -0.0409 * * * \\ (0.00737) & (0.00813) & (0.00801) & (0.00804) \\ -0.0501 * * * & -0.0501 * * * & -0.0564 * * * & -0.0412 * * \\ (0.0154) & (0.0183) & (0.0186) & (0.0180) \\ -0.0118 & -0.0118 & -0.0129 & -0.0150 \\ (0.00826) & (0.00950) & (0.00946) & (0.00936) \\ 0.00865 * * * & 0.00865 * * * & 0.00618 * * * & 0.00254 \\ (0.00137) & (0.00151) & (0.00157) & (0.00157) \\ 0.877 * * * & 0.877 * * * & 1.165 * * * & 1.034 * * * \\ (0.0215) & (0.0246) & (0.0265) & (0.142)\end{array}$

X

$$
\begin{aligned}
& \mathrm{X} \\
& \mathrm{X}
\end{aligned}
$$

$\begin{array}{ll}\mathbf{X} & \mathbf{X} \\ \mathbf{X} & \mathbf{X} \\ \mathbf{X} & \mathbf{X} \\ & \mathbf{X}\end{array}$

details on controls 
Table X Returns to education by quartile of spending per student

\begin{tabular}{|c|c|c|c|c|}
\hline $\begin{array}{l}\text { Legalistic Informality } \\
(\text { No Pension }=1)\end{array}$ & $\begin{array}{c}\text { (1) } \\
\text { 1st quartile }\end{array}$ & $\begin{array}{c}\text { (2) } \\
\text { 2nd quartile }\end{array}$ & $\begin{array}{c}\text { (3) } \\
\text { 3rd quartile }\end{array}$ & $\begin{array}{c}\text { (4) } \\
\text { 4th quartile }\end{array}$ \\
\hline Indigenous & $\begin{array}{l}-0.0297 \\
(0.0302)\end{array}$ & $\begin{array}{l}-0.00711 \\
(0.0343)\end{array}$ & $\begin{array}{c}0.0306 \\
(0.0285)\end{array}$ & $\begin{array}{c}0.0306 \\
(0.0303)\end{array}$ \\
\hline Primary & $\begin{array}{c}-0.0608 * * * \\
(0.0161)\end{array}$ & $\begin{array}{l}-0.0284 \\
(0.0232)\end{array}$ & $\begin{array}{l}-0.0189 \\
(0.0249)\end{array}$ & $\begin{array}{l}-0.0218 \\
(0.0242)\end{array}$ \\
\hline Secondary & $\begin{array}{c}-0.241 * * * \\
(0.0292)\end{array}$ & $\begin{array}{c}-0.196 * * * \\
(0.0299)\end{array}$ & $\begin{array}{c}-0.211 * * * \\
(0.0360)\end{array}$ & $\begin{array}{c}-0.195 * * * \\
(0.0351)\end{array}$ \\
\hline Tertiary & $\begin{array}{l}-0.502 * * * \\
(0.0408)\end{array}$ & $\begin{array}{l}-0.505 * * * \\
(0.0433)\end{array}$ & $\begin{array}{c}-0.456^{* * * *} \\
(0.0413)\end{array}$ & $\begin{array}{c}-0.489 * * * \\
(0.0417)\end{array}$ \\
\hline I*Primary & $\begin{array}{c}0.0186 \\
(0.0317)\end{array}$ & $\begin{array}{l}0.00157 \\
(0.0322)\end{array}$ & $\begin{array}{l}-0.0274 \\
(0.0312)\end{array}$ & $\begin{array}{l}-0.0569^{*} \\
(0.0311)\end{array}$ \\
\hline I*Secondary & $\begin{array}{l}0.127 * * * \\
(0.0423)\end{array}$ & $\begin{array}{l}0.0832 * \\
(0.0470)\end{array}$ & $\begin{array}{l}0.0823^{*} \\
(0.0443)\end{array}$ & $\begin{array}{c}0.0223 \\
(0.0466)\end{array}$ \\
\hline I*Tertiary & $\begin{array}{l}-0.0259 \\
(0.0568)\end{array}$ & $\begin{array}{l}-0.00794 \\
(0.0612)\end{array}$ & $\begin{array}{c}0.0666 \\
(0.0713)\end{array}$ & $\begin{array}{c}0.0561 \\
(0.0695)\end{array}$ \\
\hline Public School & $\begin{array}{l}-0.0141 \\
(0.0257)\end{array}$ & $\begin{array}{l}0.00127 \\
(0.0283)\end{array}$ & $\begin{array}{l}-0.0261 \\
(0.0327)\end{array}$ & $\begin{array}{l}-0.0540^{*} \\
(0.0290)\end{array}$ \\
\hline Rural & $\begin{array}{c}0.0806^{* * *} \\
(0.0302)\end{array}$ & $\begin{array}{c}0.0217 \\
(0.0311)\end{array}$ & $\begin{array}{l}-0.0101 \\
(0.0312)\end{array}$ & $\begin{array}{c}0.0396 \\
(0.0343)\end{array}$ \\
\hline Female & $\begin{array}{l}0.194 * * * \\
(0.0238)\end{array}$ & $\begin{array}{l}0.196 * * * \\
(0.0170)\end{array}$ & $\begin{array}{l}0.215 * * * \\
(0.0215)\end{array}$ & $\begin{array}{l}0.226 * * * \\
(0.0213)\end{array}$ \\
\hline Married & $\begin{array}{l}-0.0193 \\
(0.0145)\end{array}$ & $\begin{array}{l}0.00128 \\
(0.0142)\end{array}$ & $\begin{array}{l}-0.0256^{*} \\
(0.0143)\end{array}$ & $\begin{array}{c}0.0187 \\
(0.0155)\end{array}$ \\
\hline Chronic Illness & $\begin{array}{c}-0.0402^{* *} \\
(0.0160)\end{array}$ & $\begin{array}{l}-0.0201 \\
(0.0144)\end{array}$ & $\begin{array}{l}-0.0176 \\
(0.0169)\end{array}$ & $\begin{array}{l}-0.00559 \\
(0.0154)\end{array}$ \\
\hline Migrated & $\begin{array}{l}-0.0239 \\
(0.0198)\end{array}$ & $\begin{array}{c}0.0134 \\
(0.0150)\end{array}$ & $\begin{array}{c}0.0129 \\
(0.0171)\end{array}$ & $\begin{array}{c}-0.000487 \\
(0.0205)\end{array}$ \\
\hline Tenure & $\begin{array}{c}0.00124 \\
(0.000801)\end{array}$ & $\begin{array}{c}0.00212 * * * \\
(0.000614)\end{array}$ & $\begin{array}{c}0.00269^{* * *} \\
(0.000743)\end{array}$ & $\begin{array}{c}0.00316^{* * *} \\
(0.000733)\end{array}$ \\
\hline Bedrooms & $\begin{array}{c}-0.0112 * * \\
(0.00501)\end{array}$ & $\begin{array}{l}-0.00841 \\
(0.00572)\end{array}$ & $\begin{array}{l}-0.00609 \\
(0.00445)\end{array}$ & $\begin{array}{l}-0.00487 \\
(0.00475)\end{array}$ \\
\hline Electricity & $\begin{array}{l}-0.0399^{*} \\
(0.0209)\end{array}$ & $\begin{array}{c}-0.0568 * * * \\
(0.0173)\end{array}$ & $\begin{array}{l}-0.0310 \\
(0.0204)\end{array}$ & $\begin{array}{l}-0.0255 \\
(0.0259)\end{array}$ \\
\hline Piped Water & $\begin{array}{l}-0.0233 \\
(0.0200)\end{array}$ & $\begin{array}{c}-0.0408^{* *} \\
(0.0196)\end{array}$ & $\begin{array}{c}-0.0473 * * \\
(0.0198)\end{array}$ & $\begin{array}{l}0.00577 \\
(0.0289)\end{array}$ \\
\hline Landline & $\begin{array}{l}-0.0273 \\
(0.0215)\end{array}$ & $\begin{array}{c}-0.0628 * * \\
(0.0245)\end{array}$ & $\begin{array}{l}-0.0452 \\
(0.0322)\end{array}$ & $\begin{array}{c}-0.125 * * * \\
(0.0300)\end{array}$ \\
\hline Mobile & $\begin{array}{c}-0.0520 * * * \\
(0.0151)\end{array}$ & $\begin{array}{c}-0.0537 * * * \\
(0.0179)\end{array}$ & $\begin{array}{r}-0.00913 \\
(0.0187)\end{array}$ & $\begin{array}{c}-0.0493 * * * \\
(0.0178)\end{array}$ \\
\hline Internet & $\begin{array}{l}-0.0791^{*} \\
(0.0476)\end{array}$ & $\begin{array}{l}-0.0234 \\
(0.0320)\end{array}$ & $\begin{array}{l}-0.0866 \\
(0.0538)\end{array}$ & $\begin{array}{c}0.0277 \\
(0.0334)\end{array}$ \\
\hline Sanitation & -0.00654 & -0.00455 & $-0.0386^{*}$ & -0.0170 \\
\hline
\end{tabular}




\begin{tabular}{lcccc} 
& $(0.0219)$ & $(0.0165)$ & $(0.0199)$ & $(0.0200)$ \\
Constant & $1.011 * * *$ & $0.537 * * *$ & $0.694 * * *$ & $0.858 * * *$ \\
& $(0.0906)$ & $(0.0761)$ & $(0.0974)$ & $(0.102)$ \\
& 3,056 & 3,049 & 2,921 & 3,196 \\
Observations & 0.404 & 0.414 & 0.460 & 0.423 \\
R-squared & \multicolumn{4}{l}{$\begin{array}{l}\text { Note: } * * * \mathrm{p}<0.01, * * \mathrm{p}<0.05, * \mathrm{p}<0.1 \text {. Robust standard errors in parentheses. Results present } \\
\text { most conservative specification from Table II. }\end{array}$}
\end{tabular}


Table XI Returns to education by quartile of class size

\begin{tabular}{|c|c|c|c|c|}
\hline $\begin{array}{l}\text { Legalistic Informality } \\
(\text { No Pension }=1)\end{array}$ & $\begin{array}{c}(1) \\
\text { 1st quartile }\end{array}$ & $\begin{array}{c}\text { (2) } \\
\text { 2nd quartile }\end{array}$ & $\begin{array}{c}\text { (3) } \\
\text { 3rd quartile }\end{array}$ & $\begin{array}{c}\text { (4) } \\
\text { 4th quartile }\end{array}$ \\
\hline Indigenous & $\begin{array}{c}0.0325 \\
(0.0262)\end{array}$ & $\begin{array}{l}0.0557^{*} \\
(0.0298)\end{array}$ & $\begin{array}{c}-0.0540 * * \\
(0.0227)\end{array}$ & $\begin{array}{l}-0.0140 \\
(0.0377)\end{array}$ \\
\hline Primary & $\begin{array}{c}-0.0335^{* *} \\
(0.0161)\end{array}$ & $\begin{array}{l}-0.0342 \\
(0.0233)\end{array}$ & $\begin{array}{c}-0.0442 * * \\
(0.0188)\end{array}$ & $\begin{array}{l}-0.0220 \\
(0.0227)\end{array}$ \\
\hline Secondary & $\begin{array}{c}-0.179 * * * \\
(0.0298)\end{array}$ & $\begin{array}{c}-0.185^{* * *} \\
(0.0326)\end{array}$ & $\begin{array}{c}-0.215^{* * *} \\
(0.0269)\end{array}$ & $\begin{array}{c}-0.225^{* * *} \\
(0.0284)\end{array}$ \\
\hline Tertiary & $\begin{array}{c}-0.479 * * * \\
(0.0381)\end{array}$ & $\begin{array}{c}-0.440 * * * \\
(0.0506)\end{array}$ & $\begin{array}{c}-0.510 * * * \\
(0.0350)\end{array}$ & $\begin{array}{c}-0.510 * * * \\
(0.0375)\end{array}$ \\
\hline I*Primary & $\begin{array}{l}-0.0315 \\
(0.0239)\end{array}$ & $\begin{array}{l}-0.0165 \\
(0.0293)\end{array}$ & $\begin{array}{l}-0.00605 \\
(0.0291)\end{array}$ & $\begin{array}{l}-0.0288 \\
(0.0437)\end{array}$ \\
\hline I*Secondary & $\begin{array}{l}0.000712 \\
(0.0369)\end{array}$ & $\begin{array}{c}0.0443 \\
(0.0395)\end{array}$ & $\begin{array}{l}0.127 * * * \\
(0.0395)\end{array}$ & $\begin{array}{c}0.101^{*} \\
(0.0546)\end{array}$ \\
\hline I*Tertiary & $\begin{array}{l}-0.0678 \\
(0.0547)\end{array}$ & $\begin{array}{l}-0.0241 \\
(0.0661)\end{array}$ & $\begin{array}{c}0.125^{*} \\
(0.0700)\end{array}$ & $\begin{array}{l}-0.0125 \\
(0.0553)\end{array}$ \\
\hline Public School & $\begin{array}{l}-0.0282 \\
(0.0328)\end{array}$ & $\begin{array}{c}-0.000279 \\
(0.0295)\end{array}$ & $\begin{array}{l}-0.0337 \\
(0.0248)\end{array}$ & $\begin{array}{l}-0.0187 \\
(0.0253)\end{array}$ \\
\hline Rural & $\begin{array}{l}0.00929 \\
(0.0406)\end{array}$ & $\begin{array}{l}0.0463 * * \\
(0.0226)\end{array}$ & $\begin{array}{c}0.0822 * * * \\
(0.0241)\end{array}$ & $\begin{array}{c}0.0178 \\
(0.0315)\end{array}$ \\
\hline Female & $\begin{array}{l}0.170 * * * \\
(0.0161)\end{array}$ & $\begin{array}{l}0.202 * * * \\
(0.0195)\end{array}$ & $\begin{array}{l}0.196 * * * \\
(0.0242)\end{array}$ & $\begin{array}{l}0.250^{* * *} \\
(0.0176)\end{array}$ \\
\hline Married & $\begin{array}{c}0.0175 \\
(0.0124)\end{array}$ & $\begin{array}{l}-0.0106 \\
(0.0146)\end{array}$ & $\begin{array}{c}-0.0384 * * * \\
(0.0109)\end{array}$ & $\begin{array}{l}0.00430 \\
(0.0150)\end{array}$ \\
\hline Chronic Illness & $\begin{array}{l}-0.0226 \\
(0.0138)\end{array}$ & $\begin{array}{l}-0.00717 \\
(0.0166)\end{array}$ & $\begin{array}{l}-0.00543 \\
(0.0142)\end{array}$ & $\begin{array}{l}-0.0221 \\
(0.0142)\end{array}$ \\
\hline Migrated & $\begin{array}{l}0.0385^{* *} \\
(0.0176)\end{array}$ & $\begin{array}{l}-0.00233 \\
(0.0195)\end{array}$ & $\begin{array}{r}-0.00893 \\
(0.0184)\end{array}$ & $\begin{array}{l}-0.00700 \\
(0.0137)\end{array}$ \\
\hline Tenure & $\begin{array}{c}0.00330 * * * \\
(0.000537)\end{array}$ & $\begin{array}{c}0.00301 * * * \\
(0.000570)\end{array}$ & $\begin{array}{l}0.00194 * * \\
(0.000778)\end{array}$ & $\begin{array}{c}0.000850 \\
(0.000797)\end{array}$ \\
\hline Bedrooms & $\begin{array}{c}-0.00749 * \\
(0.00394)\end{array}$ & $\begin{array}{l}-0.00639 \\
(0.00416)\end{array}$ & $\begin{array}{l}-0.00591 \\
(0.00384)\end{array}$ & $\begin{array}{c}-0.01000 * * \\
(0.00492)\end{array}$ \\
\hline Electricity & $\begin{array}{l}-0.0153 \\
(0.0181)\end{array}$ & $\begin{array}{c}-0.0393 * * \\
(0.0169)\end{array}$ & $\begin{array}{c}-0.0451 * * \\
(0.0183)\end{array}$ & $\begin{array}{c}-0.0810^{* * *} \\
(0.0265)\end{array}$ \\
\hline Piped Water & $\begin{array}{l}-0.0161 \\
(0.0186)\end{array}$ & $\begin{array}{c}-0.0401 * * \\
(0.0177)\end{array}$ & $\begin{array}{l}-0.0212 \\
(0.0186)\end{array}$ & $\begin{array}{l}-0.0213 \\
(0.0232)\end{array}$ \\
\hline Landline & $\begin{array}{c}-0.0675^{* * *} \\
(0.0321)\end{array}$ & $\begin{array}{c}-0.0705^{* *} \\
(0.0330)\end{array}$ & $\begin{array}{l}-0.0489^{*} \\
(0.0247)\end{array}$ & $\begin{array}{c}-0.0473 * * \\
(0.0194)\end{array}$ \\
\hline Mobile & $\begin{array}{c}-0.0403 * * * \\
(0.0144)\end{array}$ & $\begin{array}{l}-0.0186 \\
(0.0152)\end{array}$ & $\begin{array}{c}-0.0426 * * * \\
(0.0131)\end{array}$ & $\begin{array}{c}-0.0535^{* *} \\
(0.0219)\end{array}$ \\
\hline Internet & $\begin{array}{l}-0.0129 \\
(0.0435)\end{array}$ & $\begin{array}{l}-0.0129 \\
(0.0380)\end{array}$ & $\begin{array}{l}-0.0171 \\
(0.0305)\end{array}$ & $\begin{array}{c}-0.0743 * * \\
(0.0352)\end{array}$ \\
\hline Sanitation & $\begin{array}{l}-0.0274^{*} \\
(0.0157)\end{array}$ & $\begin{array}{l}-0.0243 \\
(0.0174)\end{array}$ & $\begin{array}{c}0.0111 \\
(0.0195)\end{array}$ & $\begin{array}{l}-0.00641 \\
(0.0198)\end{array}$ \\
\hline
\end{tabular}




\begin{tabular}{|c|c|c|c|c|}
\hline Constant & $\begin{array}{c}0.525 * * \\
(0.248)\end{array}$ & $\begin{array}{c}0.938 * * * \\
(0.0834)\end{array}$ & $\begin{array}{l}1.107 * * * \\
(0.0836)\end{array}$ & $\begin{array}{c}0.398 * * * \\
(0.0716)\end{array}$ \\
\hline Observations & 4,048 & 3,760 & 3,516 & 3,551 \\
\hline R-squared & 0.465 & 0.417 & 0.405 & 0.376 \\
\hline
\end{tabular}


Figure 4 Net present value returns to secondary education

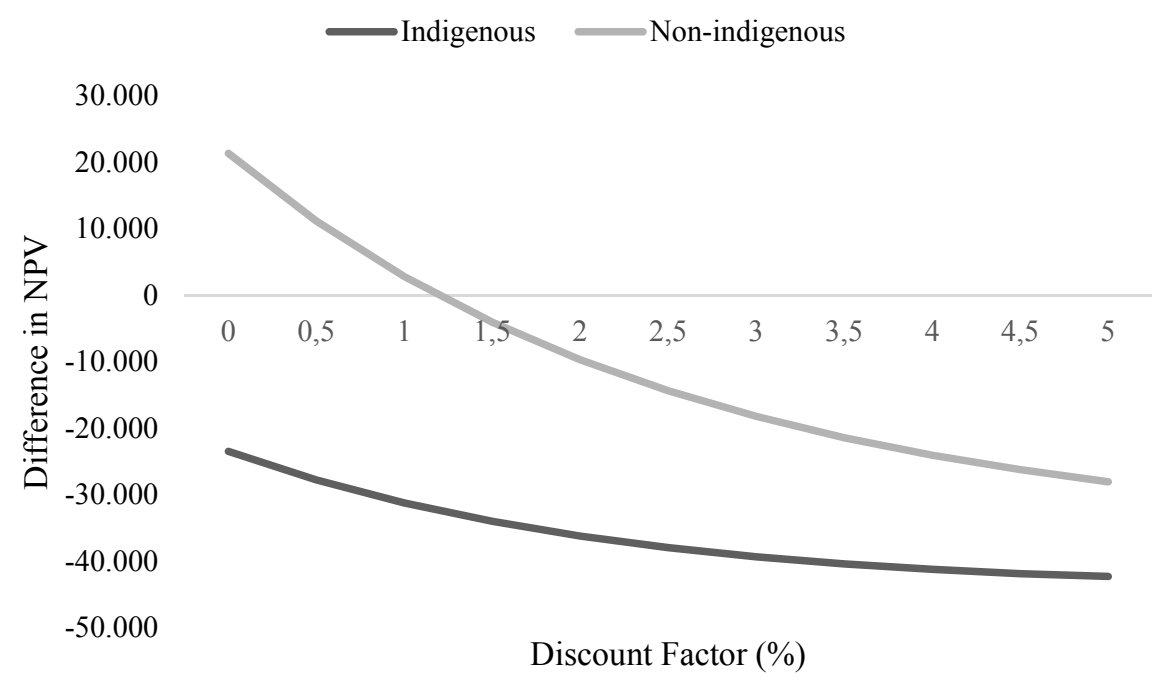

Figure illustrates the net present value expected for individuals who pursue secondary education minus the expected income of those with only completed primary education, over an array of discount rates.

Source: Author's own elaboration based on ENAHO (2010) 